\title{
On the origin and diversification of the stygobiotic freshwater snail genus Hauffenia (Caenogastropoda: Hydrobiidae) with special focus on the northern species and the description of two new species
}

\author{
Martin HAASE ${ }^{\circledR 1, *}$, Jozef GREGO ${ }^{\circledR 2}$, Zoltán Péter ERÖSS ${ }^{\circledR 3}$, \\ Roland FARKAS ${ }^{4}$ \& Zoltán FEHÉR ${ }^{\circledR} 5$ \\ ${ }^{1}$ AG Vogelwarte, Zoological Institute and Museum, University of Greifswald, \\ Soldmannstraße 23, 17489 Greifswald, Germany. \\ ${ }^{2}$ Horná Mičiná 219, 97401 Banská Bystrica, Slovakia. \\ ${ }^{3}$ Levendula utca 68/4, 2119 Pécel, Hungary. \\ ${ }^{4}$ Bükk National Park Directorate, Sánc utca 6, 3304 Eger, Hungary. \\ ${ }^{5}$ WWF Hungary, Álmos vezér útja 69/A, 1141 Budapest, Hungary. \\ "Corresponding author: martin.haase@uni-greifswald.de \\ ${ }^{2}$ Email: jozef.grego@gmail.com \\ ${ }^{3}$ Email: erosspeter@hotmail.com \\ ${ }^{4}$ Email: farkasro@yahoo.com \\ ${ }^{5}$ Email: feher.zoltan.nhmus@gmail.com

\footnotetext{
${ }^{1}$ urn:1sid:zoobank.org:author:8CE4B347-14C5-464F-99C4-DE2263FC55D5

${ }^{2}$ urn:lsid:zoobank.org:author:44C83AAB-CF4E-46E8-8146-DFBADA150AB6

${ }^{3}$ urn:lsid:zoobank.org:author:0B2C74A7-0001-4E25-984C-88CB0C705313

${ }^{4}$ urn:lsid:zoobank.org:author:9BCFB1AA-7605-4B43-937C-A659D020912B

${ }^{5}$ urn:lsid:zoobank.org:author:E801EC76-8B1E-450B-993E-BBBE57C00EA9
}

\begin{abstract}
During systematic surveys of groundwater snails in Slovakia, Hungary and Bosnia and Hercegovina two new species of the genus Hauffenia, H. lozekiana sp. nov. from a single locality in Slovakia, and H. steffeki sp. nov. with a small range in Bosnia and Hercegovina were discovered and are here described based on shell morphology, anatomy and DNA sequence data (COI, 16S rRNA, ITS2). The discovery of $H$. steffeki sp. nov. extends the range of the genus considerably towards the south. Hauffenia lozekiana sp. nov. appears to be a relict surviving within the range of the today widely distributed $H$. kissdalmae. Based on a time tree, we developed a scenario for the origin and diversification of the genus. The ancestor probably evolved in the Miocene on the Balkans and with the gradual desiccation of the Paratethys and its remnant water bodies diversified towards the north. Karstic and in particular alluvial connectivities together with changing courses of paleo-rivers probably played an important role for dispersal. Ecological observations suggest that the phreatic rhizosphere, the delicate net of tree rootlets and their exudates, are important for the existence of these groundwater snails.
\end{abstract}

Keywords. DNA taxonomy, groundwater, Miocene, Pannonian Sea, rhizosphere. 
Haase M., Grego J., Erőss Z.P., Farkas R. \& Fehér Z. 2021. On the origin and diversification of the stygobiotic freshwater snail genus Hauffenia (Caenogastropoda: Hydrobiidae) with special focus on the northern species and the description of two new species. European Journal of Taxonomy 775: 143-184.

https://doi.org/10.5852/ejt.2021.775.1555

\section{Introduction}

Hydrobioid gastropods (sensu Davis 1979) are notorious for their extreme diversity on the one hand and the difficulties they pose for identification and inference of relationships due to their small size, simple shell morphology, and high degree of convergence on the other hand (e.g., Hershler \& Ponder 1998; Wilke et al. 2000; Clark et al. 2003; Delicado et al. 2019). Molecular methods have revealed an increasing number of morphologically cryptic species and there are even genera which cannot be defined unambiguously based on shell morphological and anatomical data (e.g., Haase 2008; Zielske \& Haase 2015; Delicado et al. 2021). Many valvatiform species of the family Hydrobiidae Stimpson, 1865 characterized by a more or less depressed shell and open umbilicus are illustrative examples for species having been taxonomically misplaced due to their superficial similarities. One of these genera that has kept changing its specific composition, hence range, is Hauffenia Pollonera, 1898 (see Bodon et al. 2001 and Rysiewska et al. 2017 for partial overviews of taxonomic changes). Based on anatomical and molecular data, this genus is confirmed in Austria, northern Croatia, Hungary, northeastern Italy, Slovakia, and Slovenia (Bodon et al. 2001; Šteffek et al. 2011; Falniowski \& Szarowska 2015; Rysiewska et al. 2017).

Slovakia and Hungary were the latest countries to be added to the range of the genus. On the territory of Slovakia, empty shells of the genus were first discovered by Vojen Ložek in several springs in the Slovak Karst in 1985 (mentioned in an interview in Vesmír by Mitterová 1986), followed by several records from this region (Šteffek \& Grego 2008; Grego \& Šteffek 2010; Šteffek et al. 2011). The first record from the Bystrická Highland was also provided by Ložek (Ložek \& Galvánek 1987) from Holocene travertine deposits in Dolná Mičiná. Later, empty shells were found among flotsam of the Driekyňa brook (Šteffek \& Grego unpubl. data) and three localities of the lower Hron River (Čiliak \& Šteffek 2013). In Hungary, Majoros and Krolopp have found valvatiform hydrobiid shells in the Aggtelek Karst region in the 1990s (Gábor Majoros pers. com.), but the first published record is only from 2008, when Hauffenia kissdalmae Erőss \& Petró, 2008 was described (Erőss \& Petró 2008).

Among the species listed in MolluscaBase (2021), H. lucidula (Angelov, 1967) from Bulgaria and H. edlaueri (Schütt, 1961) from southern Dalmatia (Croatia) have only been allocated to Hauffenia based on their general shell morphology (Schütt 1961; Angelov 1967; see also Georgiev 2013). As their ranges are clearly disjunct from the range outlined above, their generic affiliation is doubtful and subject to anatomical and molecular investigation. Other species originally described as Hauffenia and later already transferred to other genera are listed in MolluscaBase (2021).

During the last 19 years, spring and groundwater snails have been systematically collected across Slovakia, Hungary as well as Bosnia and Hercegovina. Many samples contained individuals which most likely belong to Hauffenia. Screening these samples molecularly revealed two unknown species - one from Slovakia, the other one from Bosnia and Hercegovina - which are described here as new to science. These investigations including newly collected material from Austria as well as published DNA sequences retrieved from GenBank also gave rise to the development of a scenario of the origin and dispersion of the genus with special focus on the species occurring in Hungary and Slovakia. 


\section{Material and methods}

\section{Sampling}

Sampling was systematically carried out by screening sandy sediment fractions of $0.2-3 \mathrm{~mm}$ from spring heads or caves according to Grego et al. (2017). Sand samples were either sorted still wet under a stereo microscope and living specimens preserved in $99 \%$ ethanol or fixed in ethanol on the spot. The samples were obtained from the localities listed in Table 1 (Figs 1-5).

\section{Phylogenetic analyses}

Identifying species of Hauffenia based on the shell is hardly possible and the inference of relationships definitely impossible. Therefore, we aimed at a phylogenetic reconstruction based on standard DNA sequence data. However, as in quite a large proportion of our samples from Hungary and Slovakia cytochrome oxidase I (COI) could not be amplified, we sequenced only 16S rRNA (16S) and the internal transcribed spacer 2 (ITS2) across the comprehensive set of samples including two species of Kerkia Radoman, 1978 as outgroup (Table 1). Prior to sequencing, DNA was extracted using the E.Z.N.A. Mollusc DNA kit (Omega Bio-Tek). For polymerase chain reactions (PCR) we used the primer pairs 16Sar and 16Sbr (Palumbi et al. 1991) as well as ITS2-f [5'-CTAGCTGCGAGAATTAATGTGA-3' (Wade \& Mordan 2000)] and ITS2-r [5'-GGTTTCACGTACTCTTGAAC-3' (Nekola et al. 2015)], respectively. The reaction volumes of $11 \mu \mathrm{L}$ contained $1 \mu \mathrm{L}$ of DNA solution $(\sim 20 \mathrm{ng}), 5 \mu \mathrm{L}$ of HS MyTaqTM RedMix (Bioline), $0.40 \mu \mathrm{L}$ of $1 \%$ BSA, $0.25 \mu \mathrm{L}$ of each primer (from a 10 pmol stock solution), and $4.10 \mu \mathrm{L}$ water. PCR temperature profiles were: for $16 \mathrm{~S}$, denaturation at $95^{\circ} \mathrm{C}$ for $1 \mathrm{~min}$, 10 touch-down cycles comprising $20 \mathrm{~s}$ denaturation at $95^{\circ} \mathrm{C}$, annealing starting at $60^{\circ} \mathrm{C}$ and dropping by 1 degree per cycle for $20 \mathrm{~s}$, as well as 1 min extension at $72^{\circ} \mathrm{C}$, followed by another 25 cycles with annealing at $51^{\circ} \mathrm{C}$ and a final extension at $72^{\circ} \mathrm{C}$ for $5 \mathrm{~min}$; ITS2 was amplified in 30 cycles after initial denaturation at $95^{\circ} \mathrm{C}$ for $1 \mathrm{~min}$ with each cycle comprising denaturation at $95^{\circ} \mathrm{C}$ for $1 \mathrm{~min}$, annealing at $52^{\circ} \mathrm{C}$ for $1 \mathrm{~min}$, and extension at $72^{\circ} \mathrm{C}$ for $1.5 \mathrm{~min}$, again followed by a final extension at $72^{\circ} \mathrm{C}$ for 5 min. For COI and a limited number of specimens, we achieved the best results using the primer pair L1490-Alb [5'-ACTCAACGAA TCATAAAGATATTGG-3' (Gittenberger et al. 2004) and BCO [5'- GTATCGGCTGTAAAATAAGC-3' (Haase et al. 2003)] originally developed for landsnails (Haase et al. 2021). The PCR mix conformed to those of the other genes. The PCR profile comprised the following steps: denaturation at $95^{\circ} \mathrm{C}$ for $3 \mathrm{~min}, 30$ cycles denaturation at $95^{\circ} \mathrm{C}$ for $1 \mathrm{~min}$, annealing at $48^{\circ} \mathrm{C}$ for $1 \mathrm{~min}$ and extension at $72^{\circ} \mathrm{C}$ for $1.5 \mathrm{~min}$, and a final extension at $72^{\circ} \mathrm{C}$ for $7 \mathrm{~min}$. Exonuclease I and shrimp alkaline phosphatase were used to purify the PCR products. For cycle sequencing we used the ABI Big Dye Terminator Reaction Mix 3.1 (Thermo Fisher) and the PCR primers. Sequences were compiled on an ABI 3130xl Genetic Analyzer (Thermo Fisher), proof-read with Geneious ver. R10.2 (www.geneious.com) and BioEdit ver. 7.0.5.3 (Hall 1999) and submitted to GenBank (Table 2). For alignments, we used MAFFT ver. 7 (Katoh et al. 2019) with default settings. Identical sequences were identified in DAMBE 72.152 (Xia 2018) and omitted. The final alignments comprised 522 (16S), 782 (ITS2), and 535 (COI) bp, respectively.

Phylogenetic trees were reconstructed for 16S and ITS2 separately as well as jointly across the comprehensive set of specimens and for all three concatenated genes based on the intersect of available individuals in maximum likelihood (ML) and Bayesian frameworks using W-IQ-TREE (Trifinopoulos et al. 2016) and MrBayes ver. 3.2.6 (Ronquist et al. 2012), respectively. Substitution models were fitted to both genes by a fast version of PartitionFinder (Lanfear et al. 2012) implemented in W-IQ-TREE and by jModeltest ver. 2.1.4 (Darriba et al. 2012) for MrBayes ver. 3.2.6. Both approaches identified HKY + I, $\mathrm{K} 2 \mathrm{P}+\Gamma+\mathrm{I}$, and $\mathrm{HKY}+\Gamma$ as best-fitting models for $16 \mathrm{~S}$, ITS2, and COI, respectively. The W-IQ-TREE analysis ran with linked edges and 1000 replicates of ultrafast bootstrapping (Minh et al. 2013). MrBayes was run for 10 mio generations logging every $1000^{\text {th }}$ tree, a burn-in of $25 \%$, and otherwise default settings. Convergence of parameter estimates was monitored by the diagnostics implemented in MrBayes. 


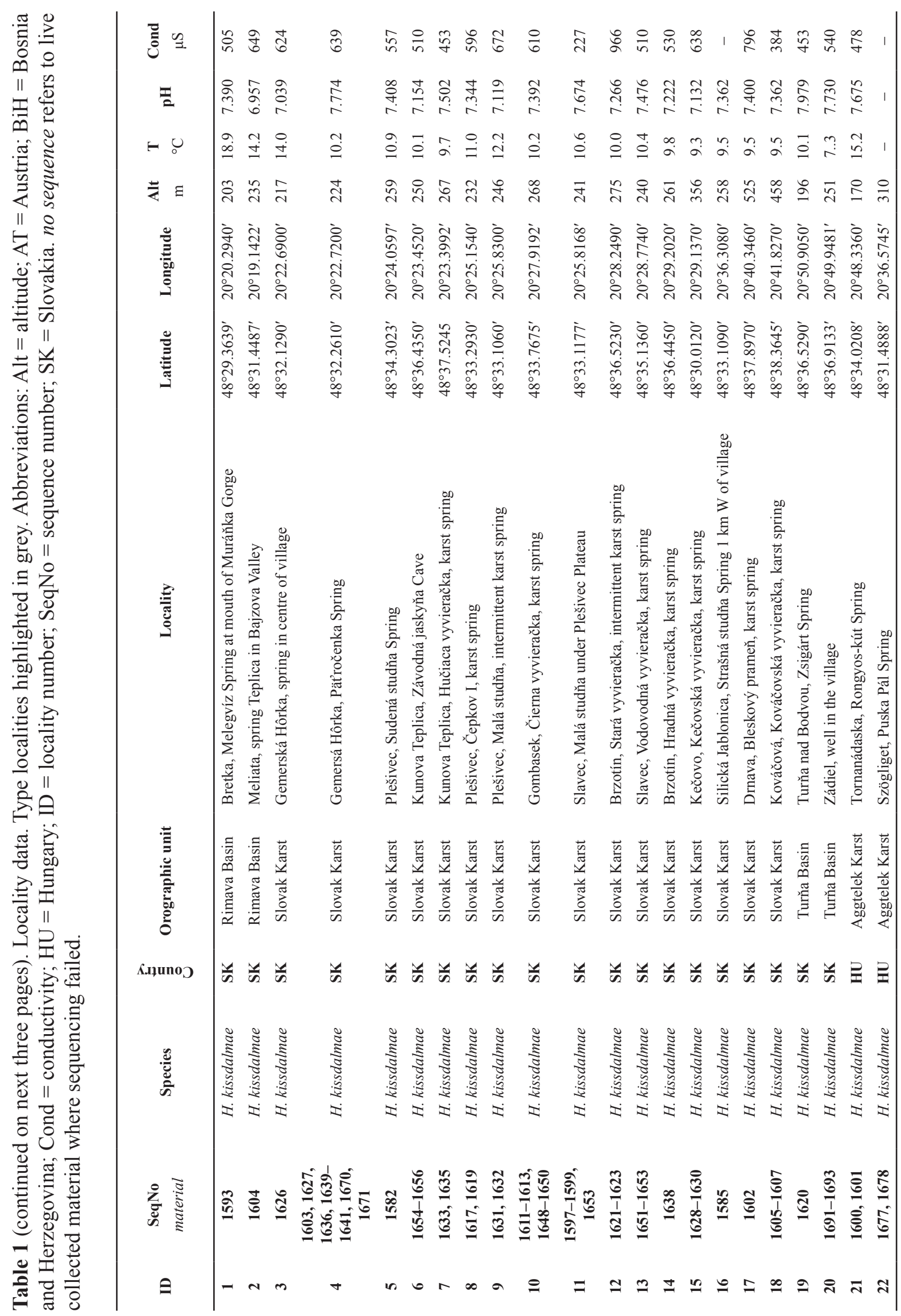




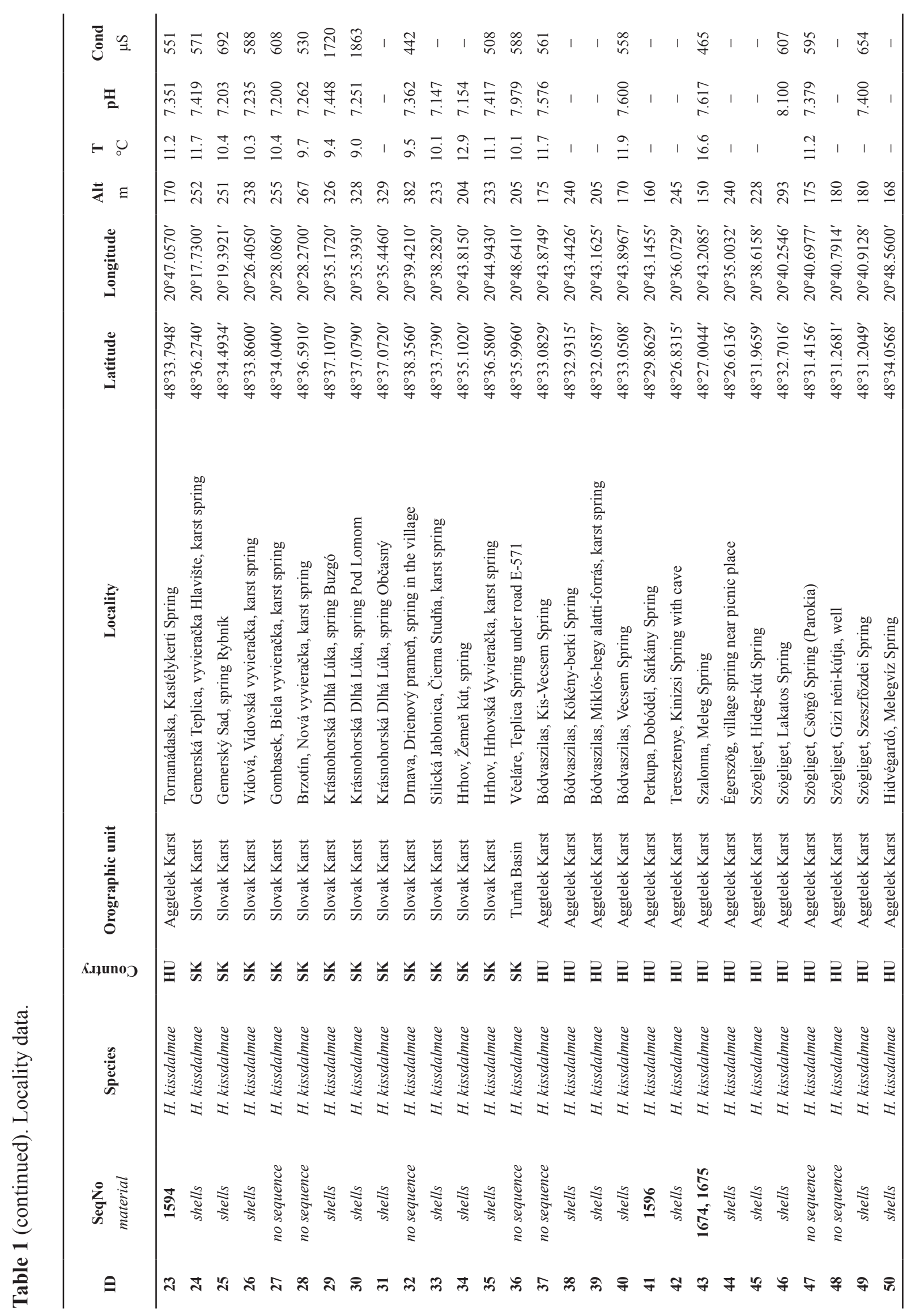









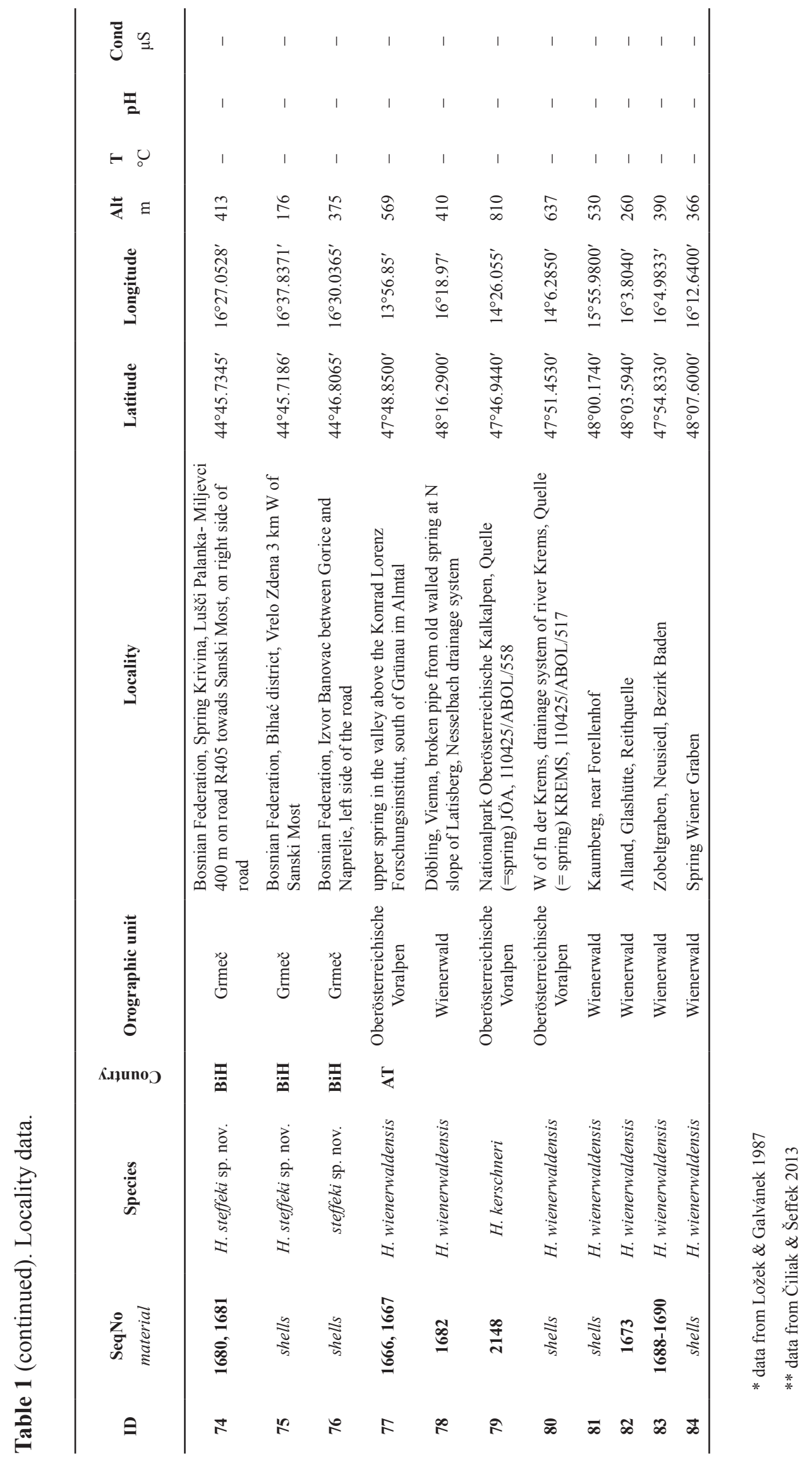




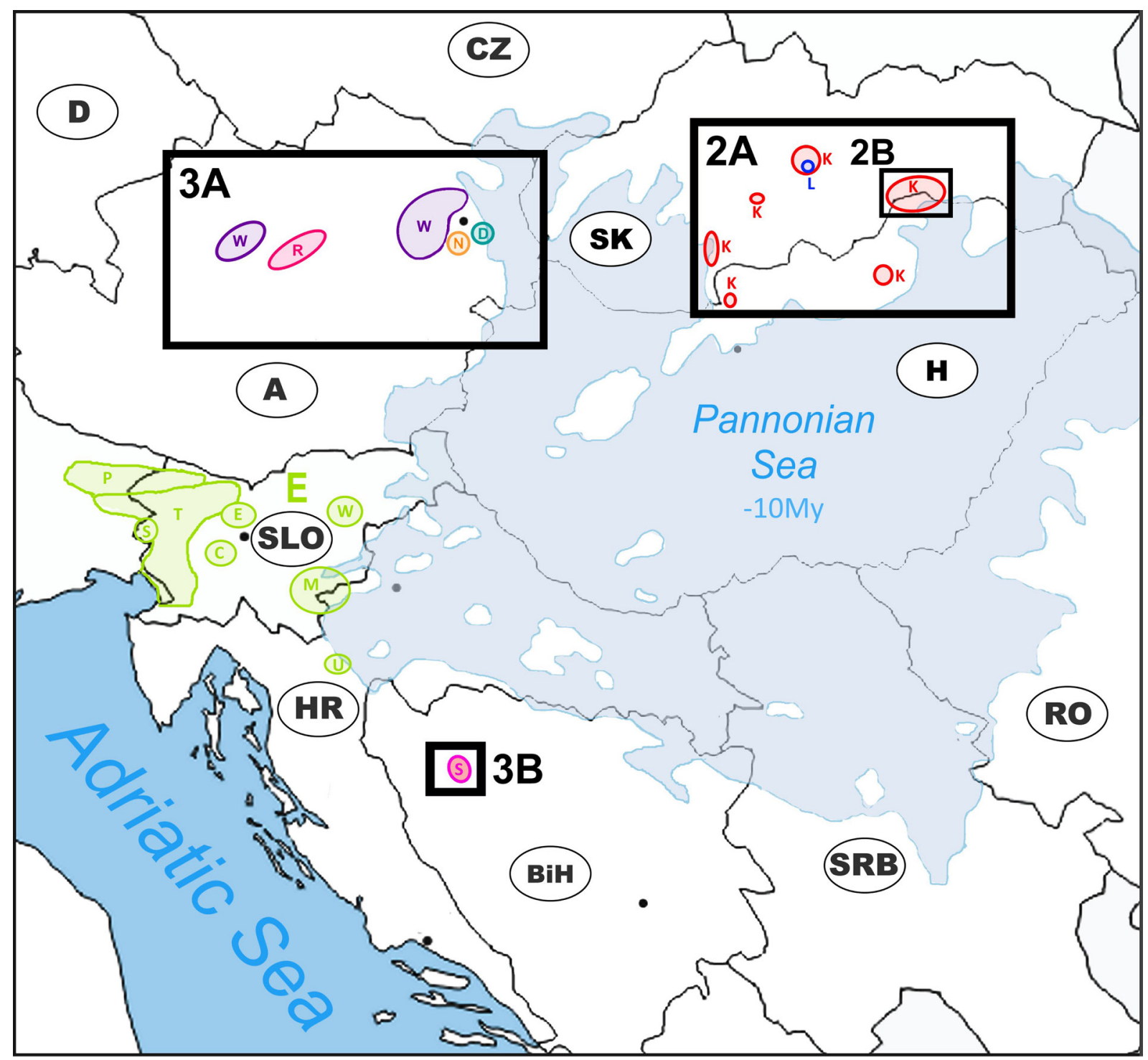

LEGEND:

Area presented by a detailed map:

2A

$2 \mathbf{B}$ - Slovak Karst / Aggtelek karst

3A - Northern Austria

$3 \mathbf{B}$ - Bosanska Krajina
Disstribution range of:

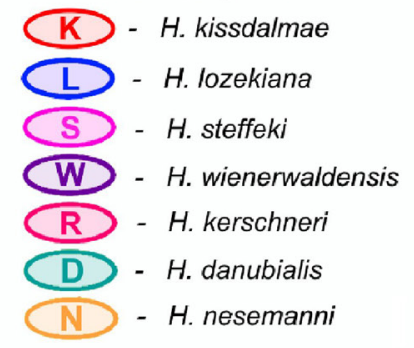

E: South Alpine species:

$\mathrm{TH}$. tellinii, E H. erythropomatia,

C H. michleri, W H. wagneri,

UH. tovunica, SH. subcarinata,

M H. media, PH. subpiscinalis

Fig. 1. Current distribution of Hauffenia Pollonera, 1898 in relation to the extension of the Pannonian Sea 10 Ma. 


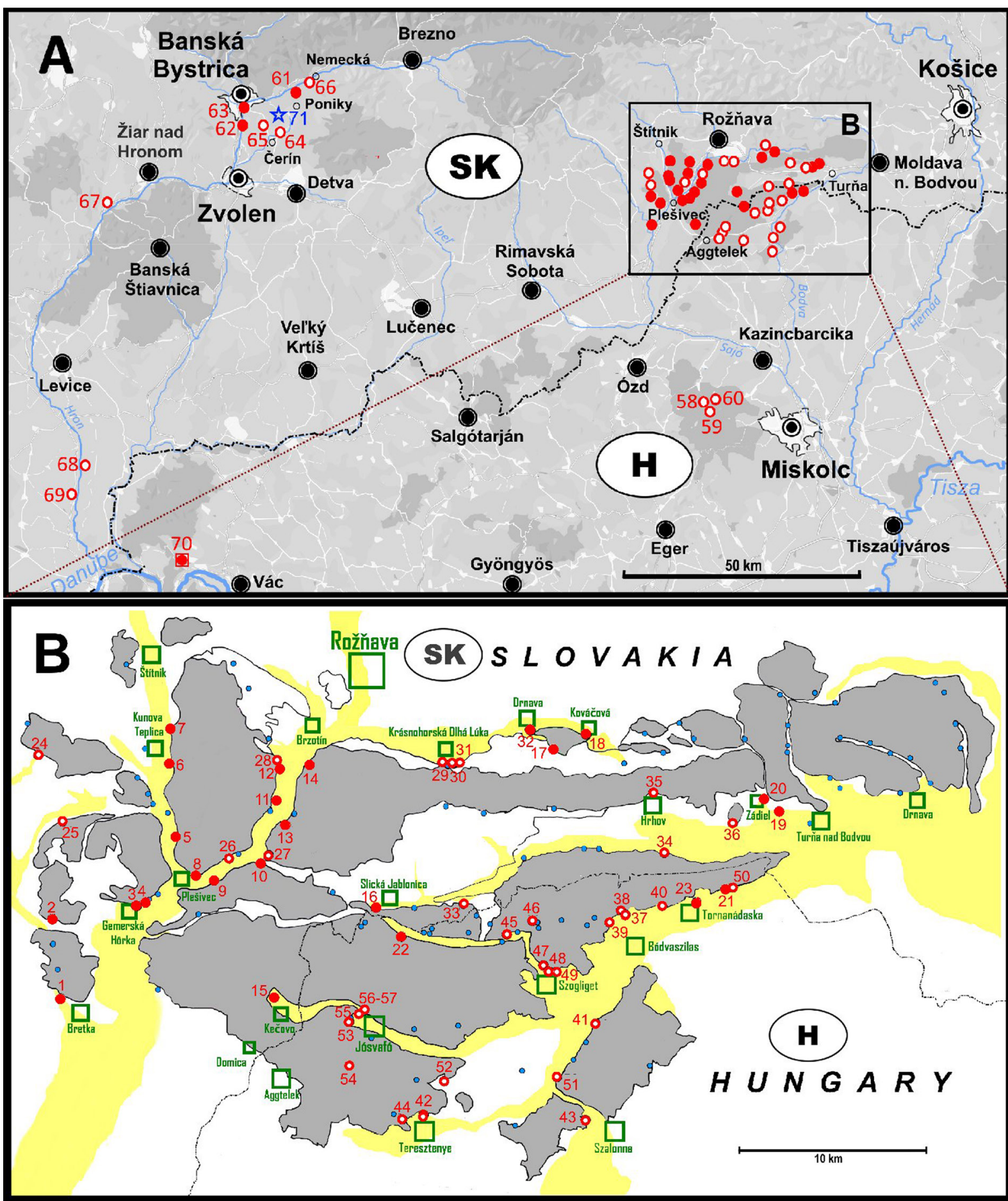

LEGEND:

Permeable carbonates (Triassic)

Permeable and conductive Alluvium

Investigated Hauffenia localities (locality numbers according to Tab. 1):

OD - H. kissdalmae - confirmed by DNA/ unconfirmed / LT

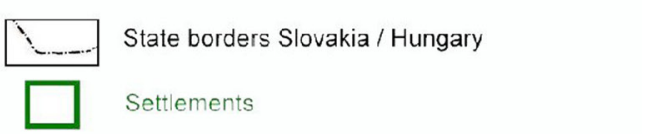

- - Springs with Hauffenia spp. so far not detected 丸 - H. lozekiana - confirmed by DNA / LT

Fig. 2. Localities in Slovakia (A) and Hungary (B). Abbreviation: LT = type locality. 


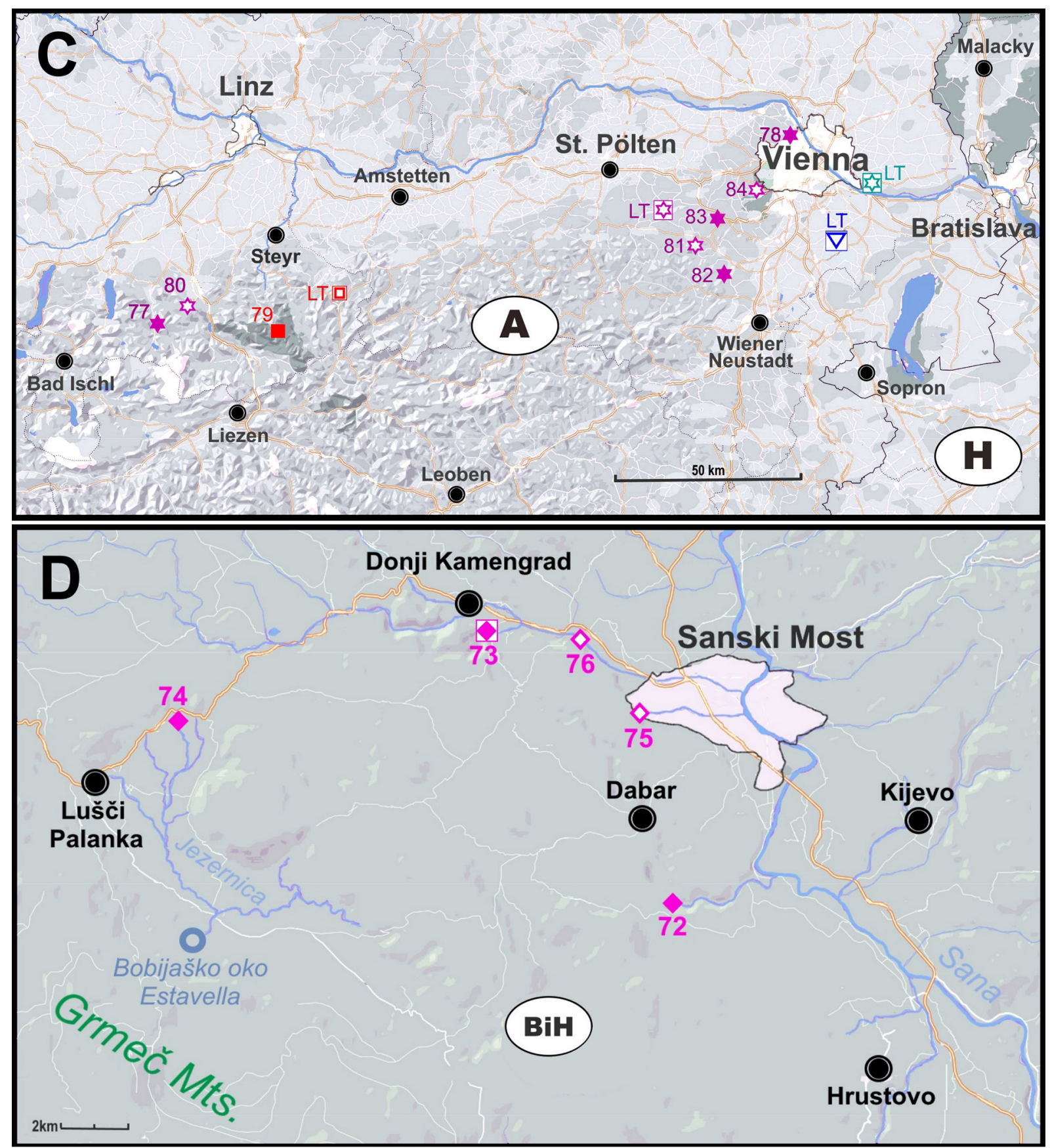

\section{LEGEND:}

Investigated Hauffenia localities (locality numbers according to Tab. 1):

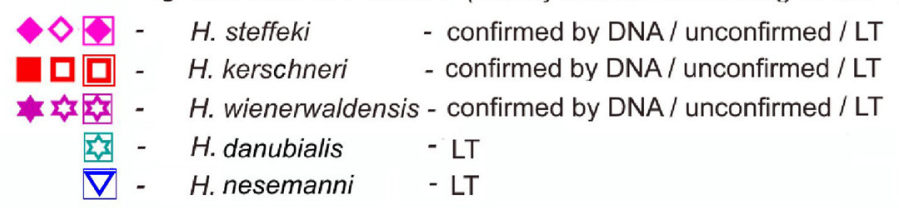

Fig. 3. Localities in Austria (C) and Bosnia and Herzegovina (D). Abbreviation: LT = type locality. 




Fig. 4. Selected localities of $H$. kissdalmae Erőss \& Petró, 2008. Image numbers correspond to locality numbers in Table 1. 


\section{Time tree}

In order to infer the temporal scenario of the diversification of Hauffenia, we reconstructed a time tree in BEAST ver. 2.6.3 (Bouckaert et al. 2019) based on COI, because this gene was available in GenBank for the largest number of species (Table 2). As already mentioned, the set of new COI sequences of Austrian, Slovak, Hungarian and Bosnian species was smaller than for 16S and ITS2 because a number of specimens failed to amplify. The new sequences were aligned together with the sequences of other species of Hauffenia as well as sequences of Peringia ulvae (Pennant, 1777) and Salenthydrobia ferrerii (Wilke, 2003) retrieved from GenBank (Table 2) using Clustal W (Thompson et al. 1994) implemented in BioEdit. The latter two species were used for time calibration as their split is the only plausibly dated case in hydrobiids (Wilke 2003; see below). There are Miocene fossils attributed to Hauffenia (Papp 1954; Reischütz 2000; Anistratenko \& Anistratenko 2009; Bandel 2010; Harzhauser et al. 2014); however, these allocations are doubtful because hydrobiid genera can rarely be identified based on shell morphology. The final alignment was trimmed to 535 positions. Substitutions were not saturated according to the test of Xia et al. (2003) executed in DAMBE. The best fitting substitution model of those implemented in BEAST suggested by jModeltest based on the Bayesian Information Criterion was again $\mathrm{HKY}+\Gamma$. The analysis in BEAST was set up using BEAUTi. We selected the birth-death model as tree prior deciding against the more commonly used Yule-model because narrow range habitat specialists such as most hydrobiids probably have a fairly high species turnover. The model comparison in Path sampler, an app provided with BEAST, remained ambiguous. For either model, we did not manage to let the marginal likelihood estimates fluctuating within the same range converge. Since the strict clock was rejected by MEGA X (Kumar et al. 2018), the log normal relaxed clock model was implemented. The split of P. ulvae and S. ferrerii associated with the Messinian salinity crisis 5.96-5.33 Ma (Krijgsman

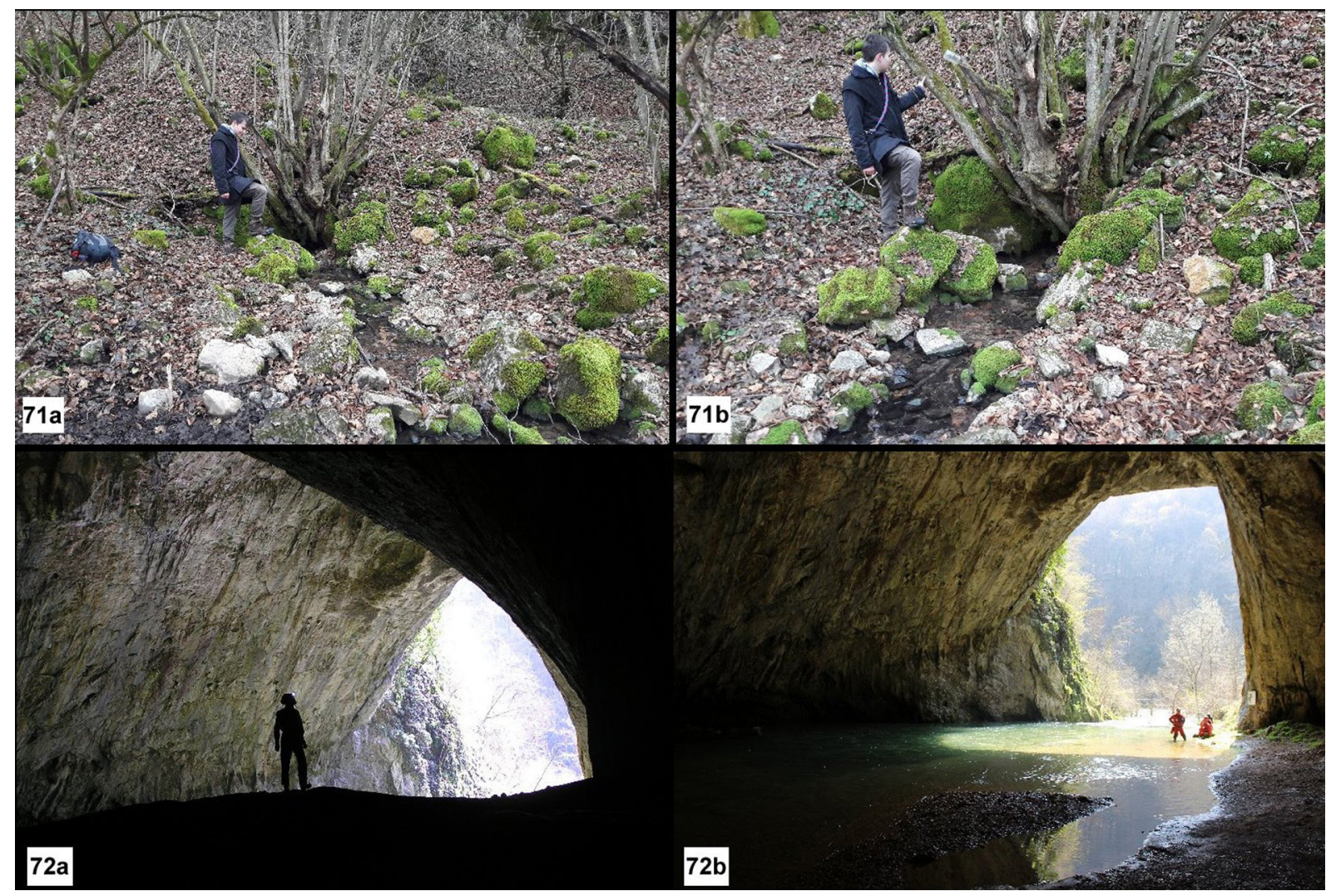

Fig. 5. Type locality of $H$. lozekiana sp. nov. (71) and Dabarska Pećina, a locality of $H$. steffeki sp. nov. (72) (see Table 1). 
HAASE M. et al., Origin and diversification of Hauffenia

Table 2 (continued on next page). GenBank accession numbers of newly sequenced specimens. Abbreviations: $\operatorname{Loc}=$ locality; Seq $=$ Sequence Number (see Table 1). Individuals with sequences identical to one of those listed here are given in Fig. 6 and Supp. file 1 (Figs S1, S3).

\begin{tabular}{|c|c|c|c|c|c|c|c|}
\hline COI & & & & $16 S$ & & & \\
\hline Species & Loc & Seq & GenBank & Species & Loc & Seq & GenBank \\
\hline H. kerschneri & 79 & 2148 & MZ408290 & H. kerschneri & 79 & 2148 & MZ424110 \\
\hline H. kissdalmae & 01 & 1593 & MZ408291 & H. kissdalmae & 01 & 1593 & MZ424111 \\
\hline H. kissdalmae & 02 & 1604 & MZ408292 & H. kissdalmae & 02 & 1604 & MZ424112 \\
\hline H. kissdalmae & 04 & 1603 & MZ408293 & H. kissdalmae & 04 & 1639 & MZ424113 \\
\hline H. kissdalmae & 05 & 1582 & MZ408294 & H. kissdalmae & 15 & 1628 & MZ424114 \\
\hline H. kissdalmae & 10 & 1611 & MZ408295 & H. kissdalmae & 19 & 1620 & MZ424115 \\
\hline H. kissdalmae & 20 & 1691 & MZ408296 & H. kissdalmae & 20 & 1691 & MZ424116 \\
\hline H. kissdalmae & 22 & 1677 & MZ408297 & H. kissdalmae & 22 & 1677 & MZ424117 \\
\hline H. kissdalmae & 22 & 1678 & MZ408298 & H. kissdalmae & 61 & 1614 & MZ424118 \\
\hline H. kissdalmae & 62 & 1663 & MZ408299 & H. lozekiana & 71 & 1610 & MZ424119 \\
\hline H. kissdalmae & 62 & 1664 & MZ408300 & H. steffeki & 73 & 1589 & MZ424120 \\
\hline H. kissdalmae & 63 & 1686 & MZ408301 & H. steffeki & 73 & 1672 & MZ424121 \\
\hline H. lozekiana & 71 & 1610 & MZ408302 & H. steffeki & 74 & 1592 & MZ424122 \\
\hline H. lozekiana & 71 & 1734 & MZ408303 & H. steffeki & 74 & 1681 & MZ424123 \\
\hline H. steffeki & 72 & 1592 & MZ408304 & H. wienerwaldensis & 77 & 1666 & MZ424124 \\
\hline H. steffeki & 73 & 1589 & MZ408305 & H. wienerwaldensis & 78 & 1682 & MZ424125 \\
\hline H. steffeki & 73 & 1672 & MZ408306 & Kerkia sp. & - & 1578 & MZ424126 \\
\hline H. steffeki & 74 & 1680 & MZ408307 & Kerkia sp. & - & 1581 & MZ424127 \\
\hline H. wienerwaldensis & 78 & 1682 & MZ408308 & Kerkia sp. & - & 1587 & MZ424128 \\
\hline H. wienerwaldensis & 82 & 1673 & MZ408309 & Kerkia sp. & - & 1588 & MZ424129 \\
\hline H. wienerwaldensis & 83 & 1688 & MZ408310 & & & & \\
\hline \multicolumn{8}{|l|}{ ITS2 } \\
\hline Species & Loc & Seq & GenBank & Species & Loc & Seq & GenBank \\
\hline H. kerschneri & 79 & 2148 & MZ424134 & H. kissdalmae & 23 & 1594 & MZ424163 \\
\hline H. kerschneri & 79 & 2149 & MZ424135 & H. kissdalmae & 23 & 1595 & MZ424164 \\
\hline H. kissdalmae & 01 & 1593 & MZ424136 & H. kissdalmae & 41 & 1596 & MZ424165 \\
\hline H. kissdalmae & 02 & 1604 & MZ424137 & H. kissdalmae & 61 & 1614 & MZ424166 \\
\hline H. kissdalmae & 03 & 1626 & MZ424138 & H. kissdalmae & 61 & 1616 & MZ424167 \\
\hline H. kissdalmae & 04 & 1603 & MZ424139 & H. kissdalmae & 61 & 1643 & MZ424168 \\
\hline H. kissdalmae & 04 & 1636 & MZ424140 & H. kissdalmae & 62 & 1663 & MZ424169 \\
\hline H. kissdalmae & 04 & 1639 & MZ424141 & H. kissdalmae & 62 & 1664 & MZ424170 \\
\hline H. kissdalmae & 04 & 1640 & MZ424142 & H. kissdalmae & 62 & 1665 & MZ424171 \\
\hline H. kissdalmae & 04 & 1641 & MZ424143 & H. kissdalmae & 63 & 1686 & MZ424172 \\
\hline H. kissdalmae & 05 & 1582 & MZ424144 & H. kissdalmae & 63 & 1687 & MZ424173 \\
\hline H. kissdalmae & 06 & 1654 & MZ424145 & H. lozekiana & 71 & 1610 & MZ424174 \\
\hline H. kissdalmae & 06 & 1656 & MZ424146 & H. steffeki & 72 & 1592 & MZ424175 \\
\hline H. kissdalmae & 08 & 1619 & MZ424147 & H. steffeki & 73 & 1589 & MZ424176 \\
\hline H. kissdalmae & 11 & 1598 & MZ424148 & H. steffeki & 73 & 1590 & MZ424177 \\
\hline
\end{tabular}


Table 2 (continued). GenBank accession numbers of newly sequenced specimens.

\begin{tabular}{lccllccc}
\hline ITS2 & & & & & & \\
\hline Species & Loc & Seq & GenBank & Species & Loc & Seq & GenBank \\
\hline H. kissdalmae & 11 & 1599 & MZ424149 & H. steffeki & 73 & 1591 & MZ424178 \\
H. kissdalmae & 13 & 1651 & MZ424150 & H. steffeki & 74 & 1680 & MZ424179 \\
H. kissdalmae & 13 & 1652 & MZ424151 & H. steffeki & 74 & 1681 & MZ424180 \\
H. kissdalmae & 13 & 1653 & MZ424152 & H. wienerwaldensis & 77 & 1667 & MZ424181 \\
H. kissdalmae & 15 & 1628 & MZ424153 & H. wienerwaldensis & 78 & 1682 & MZ424182 \\
H. kissdalmae & 15 & 1629 & MZ424154 & H. wienerwaldensis & 82 & 1673 & MZ424183 \\
H. kissdalmae & 17 & 1602 & MZ424155 & H. wienerwaldensis & 83 & 1688 & MZ424184 \\
H. kissdalmae & 18 & 1605 & MZ424156 & H. wienerwaldensis & 83 & 1689 & MZ424185 \\
H. kissdalmae & 18 & 1606 & MZ424157 & H. wienerwaldensis & 83 & 1690 & MZ424186 \\
H. kissdalmae & 20 & 1691 & MZ424158 & Kerkia sp. & - & 1578 & MZ424130 \\
H. kissdalmae & 20 & 1692 & MZ424159 & Kerkia sp. & - & 1581 & MZ424131 \\
H. kissdalmae & 20 & 1693 & MZ424160 & Kerkia sp. & - & 1587 & MZ424132 \\
H. kissdalmae & 21 & 1600 & MZ424161 & Kerkia sp. & - & 1588 & MZ424133 \\
H. kissdalmae & 21 & 1601 & MZ424162 & & & & \\
\hline
\end{tabular}

et al. 1999) separating the Mediterranean from the Atlantic Ocean was used for calibration (Wilke 2003). According to Wilke (2003), this divergence happened at the end of the crisis. However, it appears much more plausible, that the generic lineages started to separate already once the Mediterranean was cut off (Haase et al. 2007). As a consequence, we applied a uniform prior within the bounds of 5.33 to $5.96 \mathrm{Ma}$. BEAST was run twice with 20 mio generations and logging of every $1000^{\text {th }}$ tree. Both runs were combined in LogCombiner with a burnin of $25 \%$ after convergence of parameter estimates had been controlled in Tracer ver. 1.7.1 (Rambaut et al. 2018). A maximum clade credibility tree based on the remaining 30002 trees with mean node heights was constructed in TreeAnnotator.

In order to compare the topology of the ultrametric tree to unconstrained reconstructions, we conducted also a ML analysis using W-IQ-TREE with 1000 ultrafast bootstrap replicates and a Bayesian analysis in MrBayes based on the same substitution model. MrBayes ran with the same specifications as above.

\section{Network analysis}

The relationships among 16S haplotypes of $H$. kissdalmae were also analyzed by a statistical parsimony network (Clement et al. 2002) reconstructed using PopART ver. 1.7 (Leigh \& Bryant 2015) because a network probably represents close, intraspecific relationships better than a tree.

\section{Molecular diagnoses}

We also incorporated sites of COI into the diagnoses of the two new species using the R-package QUIDDICH (R-core team; Kühn \& Haase 2020). Because of the low number of fixed unique (type 1 characters sensu Kühn \& Haase 2020) and the entire lack of type 2 characters (polymorphic sites whose states are not shared with any other taxon compared), we identified type 3 (polymorphic sites with at least one state not shared with any other taxon compared) and type 4 characters (fixed unique states in pairwise comparisons) as well. In addition, we calculated genetic p-distances in MEGA X with pairwise deletion of missing sites. 


\section{Morphology}

Up to 20 shells of the new species with at least 2.125 whorls deemed subadult to adult - in contrast to other truncatelloidean genera, Hauffenia does not develop a thickened apertural lip once fully-grown and sexually mature (e.g., Verhaegen et al. 2018) - were measured from photographs taken with a Zeiss SteREO Discovery ver. 20 dissecting microscope equipped with a Plan Apo S $0.63 \times$ objective and a Zeiss Axio Cam MR3 using the program AxioVision LE (Zeiss). Shell height, shell width, aperture height and aperture width were measured parallel or perpendicular to the coiling axis. The number of whorls was counted to the nearest eighth (Kerney \& Cameron 1979).

For scanning electron microscopy (SEM), shells, opercula and radulae were cleaned in ca $2.5 \%$ sodium hypochlorite. Penes were dissected free, dehydrated in ethanol, transferred to absolute acetone, and finally dried in hexamethyldisilazane (Nation 1983). Specimens were mounted with carbon tabs and coated with palladium/platinum in a Fisons Polaron SC7640 sputter coater prior to imaging in a Zeiss EVO LS10 SEM.

\section{Abbreviations of collections}

$\begin{array}{ll}\text { HNHM } & =\text { Hungarian natural History Museum, Budapest } \\ \text { JG } & =\text { collection Jozef Grego, Banská Bystrica, Slovakia } \\ \text { NHMW } & =\text { Natural History Museum Vienna, Austria } \\ \text { NMBE } & =\text { Natural History Museum Bern, Switzerland } \\ \text { SMF } & =\text { Senckenberg Research Institute and Nature Museum, Frankfurt, Germany } \\ \text { SMOPAJ } & =\text { Slovak Museum of nature Protection and Caving, Liptovský Mikuláš, Slovakia } \\ \text { ZMH } & =\text { Zoological Museum of Hamburg, Germany } \\ \text { ZPE } & =\text { collection Zoltán Péter Erőss, Budapest, Hungary }\end{array}$

\section{Results}

\section{Phylogenetic analyses}

The separate analyses of 16S and ITS2 in MrBayes gave largely equivalent results (Supp. file 1). Each species was well supported, but their relationships remained largely unresolved. Only the sister relationship of $H$. steffeki sp. nov. to $H$. wienerwaldensis Haase, 1992 received significant support based on 16S. In the joint analysis (Fig. 6), the picture remained similar. Hauffenia steffeki sp. nov. was now sister species of all other Austrian, Hungarian and Slovak species. The Austrian species formed a clade and $H$. kissdalmae and $H$. lozekiana sp. nov. another one. However, the posterior probabilities for interspecies relationships were all below 0.95 . The single gene ML analyses produced a similarly ambiguous picture regarding species relationships as did the Bayesian analyses. In the joint analysis, H. kissdalmae was sister species to all other species, which formed a caterpillar in the order H. lozekiana sp. nov., H. kerschneri (Zimmermann, 1930), H. wienerwaldensis, and H. steffeki sp. nov. (Fig. 7). Again, species were well supported, but bootstrap values for their relationships were all $<70$.

The analyses across all three genes including the intersect of available taxa only confirmed $H$. steffeki sp. nov. as sister species to all other species with significant support (Fig. 8; Supp. file 1). Whether the Austrian species had an exclusive common ancestor and whether H. lozekiana sp. nov. was sister species of them or $H$. kissdalmae remained inconclusive.

The time tree across all newly sequenced species, five species for which sequences were available from GenBank, as well as Peringia ulvae and Salenthydrobia ferrerii used for calibration, also displayed quite ambiguous relationships (Fig. 9). Hauffenia steffeki sp. nov. was identified as sister species to all other taxa, however, with only weak support. The remaining species formed two maximally supported clades, though, one consisting of all other species from the Balkans, the other one of the northern species. Within 
these clades, relationships had again only low posterior probabilities. Because of these ambiguities and because of the considerably large highest posterior density intervals, inferences of temporal events should be made cautiously. It is probably safe to state that all intraspecific differentiation is young and most splits fall into the late Pleistocene. Most speciation events, however, appear to have occurred during the Pliocene, some possibly already in the late Miocene. The origin of Hauffenia also seems to date back into the Miocene.

In contrast to the ultrametric tree, Bayesian and ML analyses yielded only two well supported major clades, one consisting of all Balkan species with $H$. steffeki sp. nov. branching off first, and the other one of the Austrian, Hungarian and Slovak taxa. Relationships within these clades remained largely inconclusive (Supp. file 1).

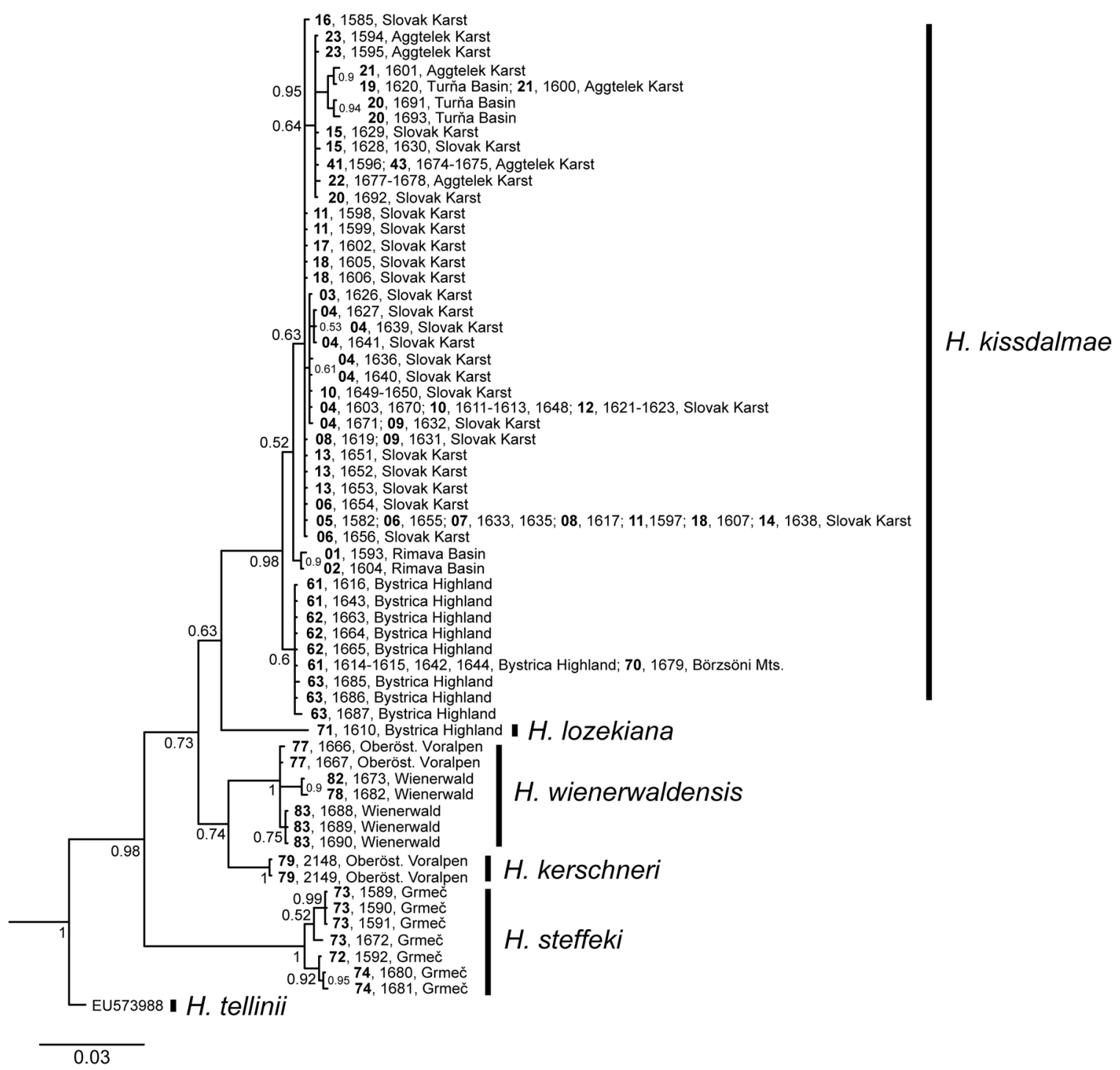

Fig. 6. Phylogenetic tree from Bayesian analysis in MrBayes based on 16S rRNA and ITS2 (outgroup pruned off). Specimens identified by two-digit locality code in bold, four digit individual DNA code, and orographic unit (see Table 1) or GenBank accession number (from Ponder et al. 2008); posterior probabilities at nodes; scale bar in substitutions per site. 
In all of these analyses including data from GenBank, the sequences attributed to $H$. erythropomatia (Hauffen, 1856) were never monophyletic.

The statistical parsimony network of $H$. kissdalmae is presented in the context of the species' distribution in the following section.

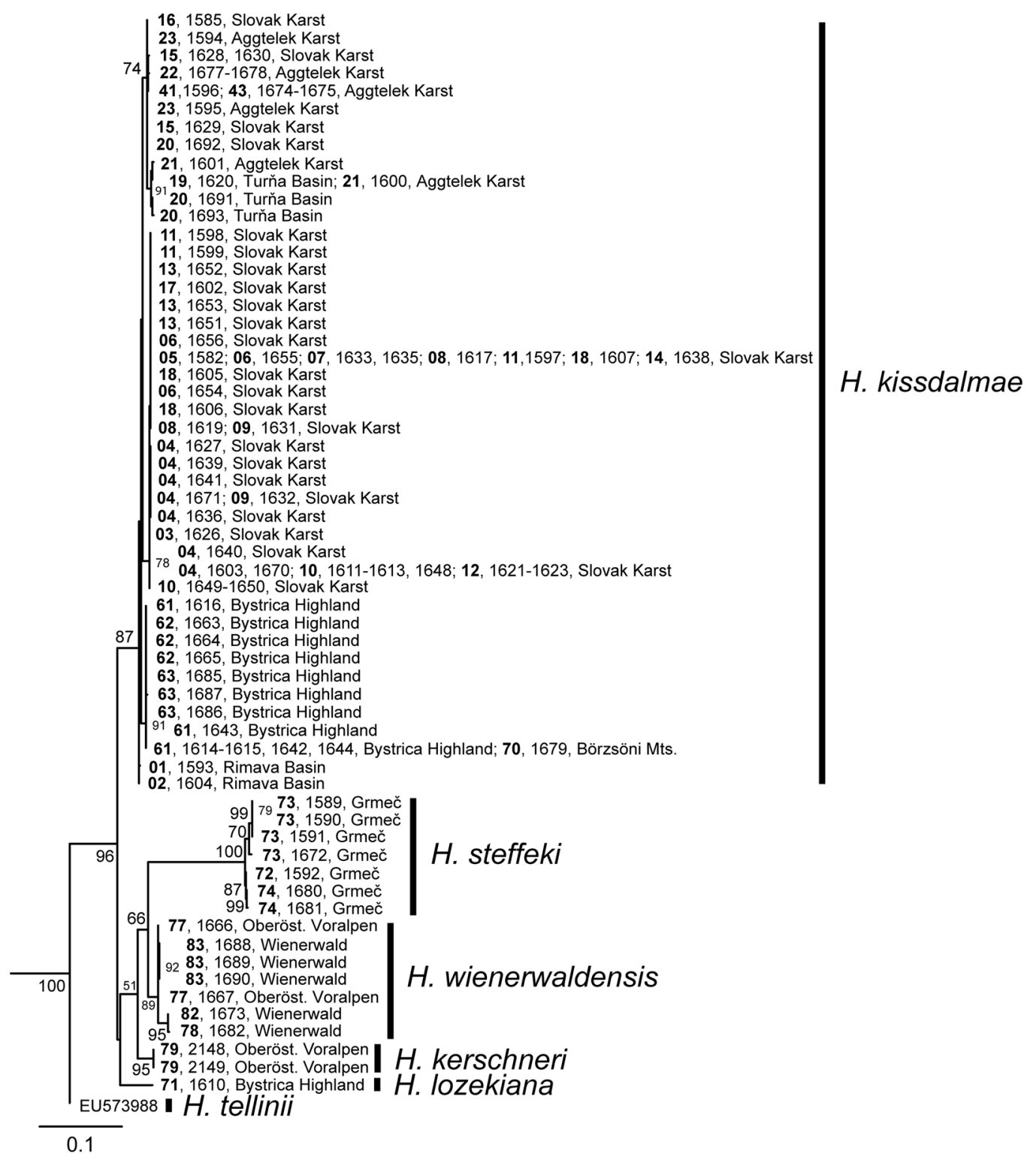

Fig. 7. Phylogenetic tree from maximum likelihood analysis in W-IQ-TREE based on 16S rRNA and ITS2 (outgroup pruned off). Specimens identified by two-digit locality code in bold, four digit individual DNA code, and orographic unit (see Table 1) or GenBank accession number (from Ponder et al. 2008); bootstrap support values at nodes $>50$; not given for extremely short nodes within $H$. kissdalmae Eröss \& Petró, 2008 and H. wienerwaldensis Haase, 1992; scale bar in substitutions per site. 


\section{Distribution and ecology of $\mathrm{H}$. kissdalmae}

Based on the molecular data presented in this study, the range of this species extends considerably northeastward from the type locality to southeast Slovakia and northeast Hungary. The type locality Kismaros at the eastern slope of the Börzsöny Mountains (Eröss \& Petró 2008) is rather an extreme point at the southwestern edge of the distribution. The main distribution of this species includes the large Mesozoic karstic formation of Gemersko-Turniansky kras (Gömor-Tornai karszt) known as Slovenský kras in Slovakia and Aggteleki karszt in Hungary, as well as in the adjacent parts of Turňa Basin and Rimava Basin. The $800 \mathrm{~km}^{2}$ karst region is well known for its well karstified plateau-type of karst with

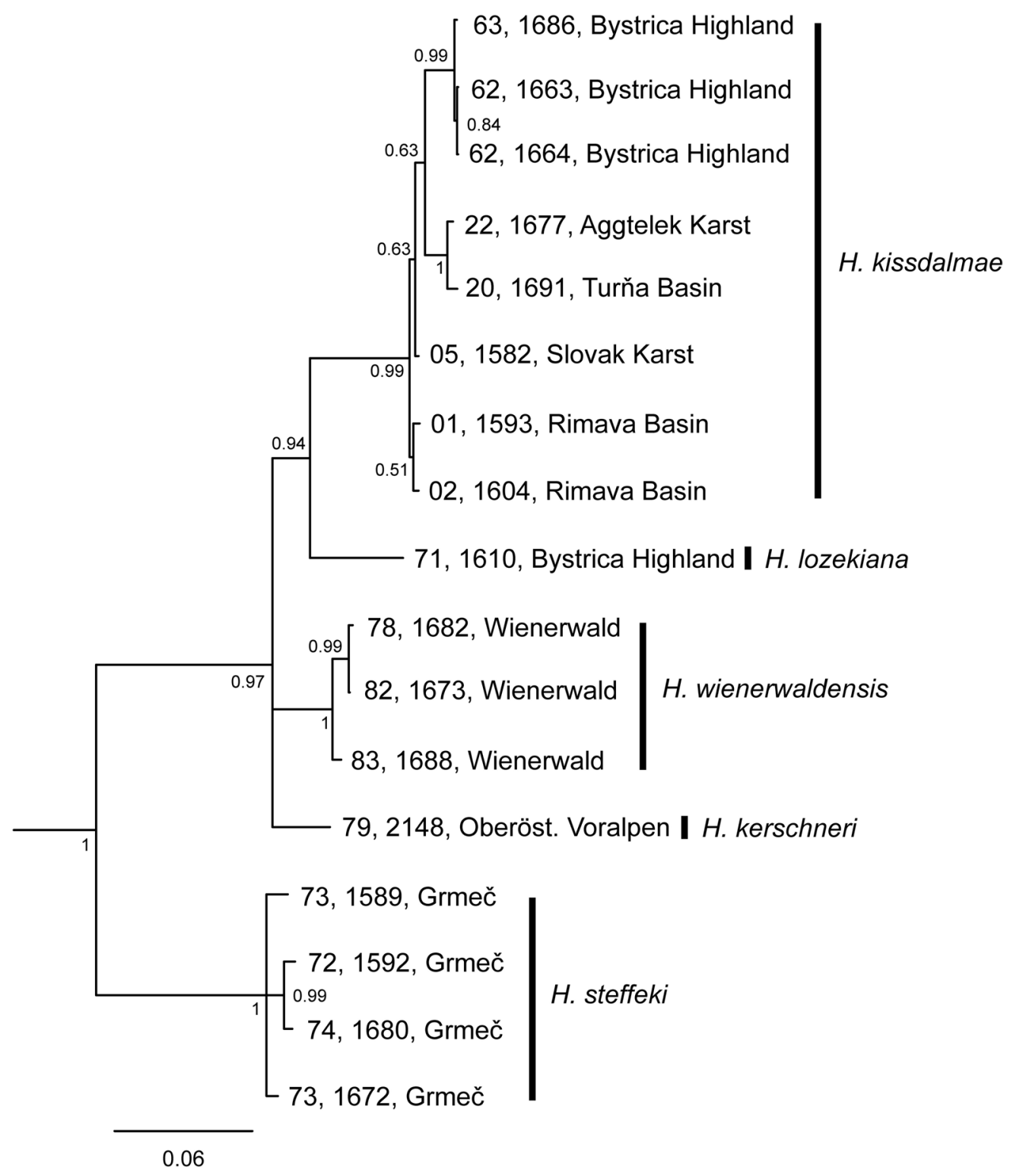

Fig. 8. Phylogenetic tree from Bayesian analysis in MrBayes based on COI, $16 \mathrm{~S}$ rRNA and ITS2 (outgroup pruned off). Specimens identified by two-digit locality code in bold, four digit individual DNA code, and orographic unit (see Table 1); posterior probabilities at nodes; scale bar in substitutions per site. 
numerous springs. The species was confirmed by molecular data in 33 spring localities in Slovakia (30) and Hungary (3) (Fig. 2). The sequencing of live collected material from further nine localities was not successful and at 24 other sites only empty shells were found. Due to geographical and hydrogeological relations among all sites we consider these records lacking molecular evidence as $\mathrm{H}$. cf. kissdalmae. In the statistical parsimony network (Fig. 10), the populations from the Slaná River alluvium with its tributaries (rivers Murán̆, Štítnik, Čremošná) and the western part of the Turňa Basin harbor the central, most common and therefore probably ancestral haplotype A. A clade containing haplotypes D and E from the Jósva and Ménes rivulets, respectively, is typical for the Bódva River alluvium in the eastern part of the range. Both rivulets as right tributaries of the Bódva River are characterized by discontinuous alluvial deposits and vanishing surface streams leaving long parts of the valleys without surface water. Therefore, the populations at the origins of the rivulets may be somewhat isolated. Haplotype $\mathrm{C}$ occurs close to the Bódva River, however, at a water temperature (ca $14^{\circ} \mathrm{C}$; Table 1) which is remarkably higher than the average karst spring in the region $\left(9.8^{\circ} \mathrm{C}\right)$. Also haplotypes $\mathrm{F}$ and $\mathrm{G}$ were collected in warm springs, Gemerská Hôrka and $\left(14^{\circ} \mathrm{C}\right)$ Bretka $\left(19^{\circ} \mathrm{C}\right)$, respectively. Whether the higher temperatures indicate local adaptation and/or are causal for the differentiation is unclear, though, as in in the Gemerská Hôrka spring haplotypes A and F were found sympatrically. More data from springs associated to Bódva alluvium would be needed to clearly understand the clade distribution.

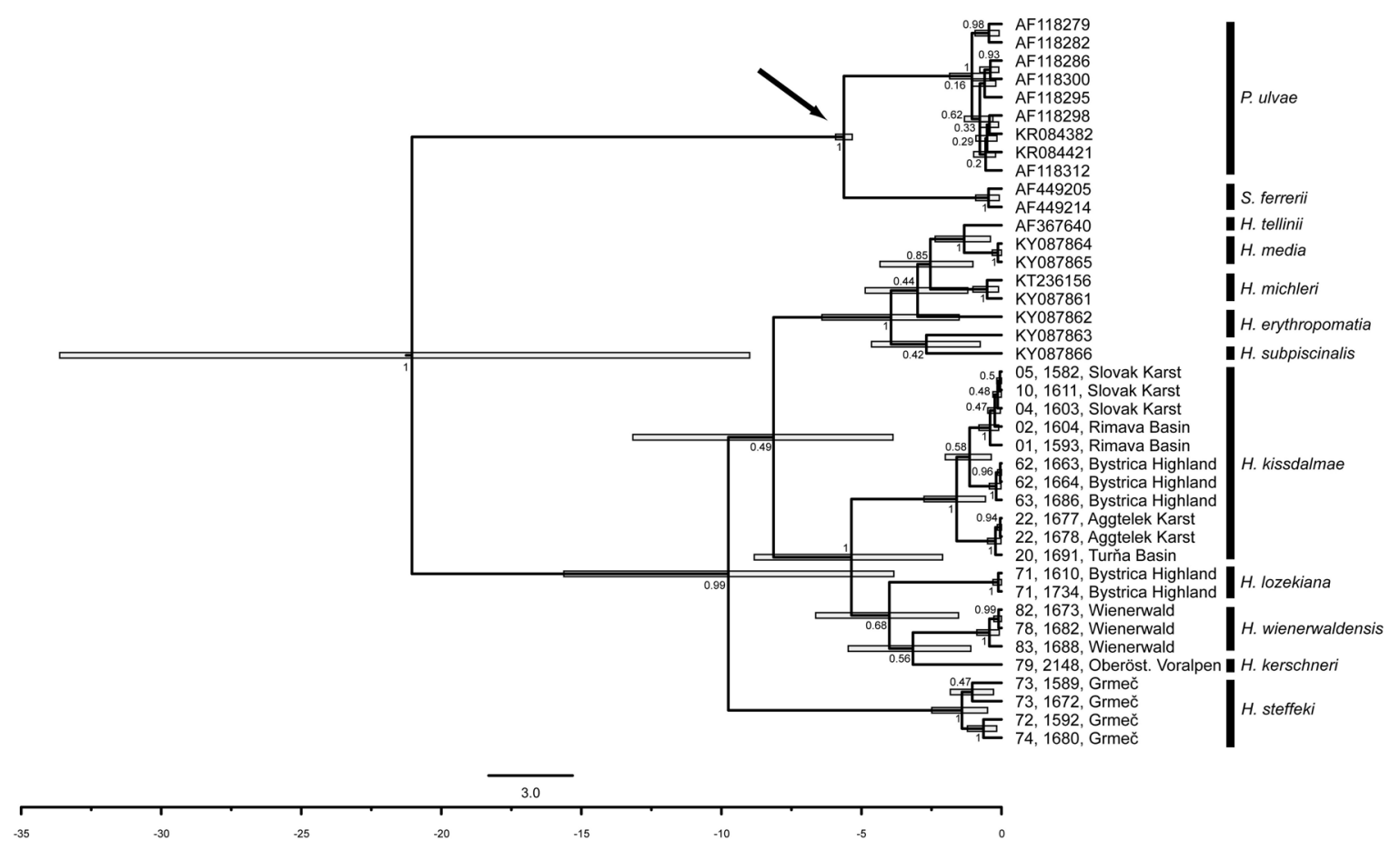

Fig. 9. Phylogenetic time-tree from Bayesian analysis in BEAST based on COI. Specimens identified by two-digit locality code in bold, four digit individual DNA code, and orographic unit (see Table 1) or GenBank accession number (from Wilke \& Davis 2000; Wilke 2003; Ponder et al. 2008; Falniowski \& Szarowska 2015; Barco et al. 2016; Rysiewska et al. 2017); posterior probabilities and highest posterior density intervals at nodes; arrow points at calibrated node; scale bar in substitutions per site; timeline on bottom in Ma before present. 
The second center of distribution was found in the Valley of the Hron River in Slovakia (haplotype H), from Nemecká through Slovenská L’upča, Banská Bystrica, Revište, and Vozokany towards its mouth into the Danube River. This geographically and hydrologically isolated group includes also the type locality of the species in Kismaros. A third isolated occurrence was just recently discovered at the northern foot of the Bükk Mountains (Hungary), but due to missing molecular data we only tentatively assigned these populations to $H$. kissdalmae.

\section{Ecology}

After the first findings of empty shells in the Slovak Karst by Vojen Ložek, it was assumed, that the species is similar and related to some of the stygobiotic Slovenian and Croatian species (Mitterová 1986; Šteffek \& Grego 2002, 2008) and inhabits the numerous caves and karst conduits of the region. The following intensive sampling of cave rivers in the region by Jozef Grego confirmed, that despite findings of numerous live specimens at the cave spring heads, the species was repeatedly not present in the cave streams except scarce dead shells near the entrance (sampled caves: Gombasek, Buzgó, Brzotínska, Misuka, Zúgó, Hrušovská, Vápená and Gemerskoteplická). For example, in the river cave Buzgó with one main direct cave outflow and three associated springs monitored in irregular intervals over 15 years, Hauffenia were consistently absent in the cave and in the direct outflow, but in the three springs associated to stony debris at least a higher number of empty shells and occasionally living specimens were found. This fact indicates, that despite the species being a stygobite adapted to underground habitats (missing eyes and pigmentation), it does not inhabit the caves itself, but is restricted to the zones of dispersed springs with stony debris (Grego \& Šteffek 2010). It was first supposed that the main food source of the species was the chemolithotrophic bacterial film covering the deep spring debris, but later indications

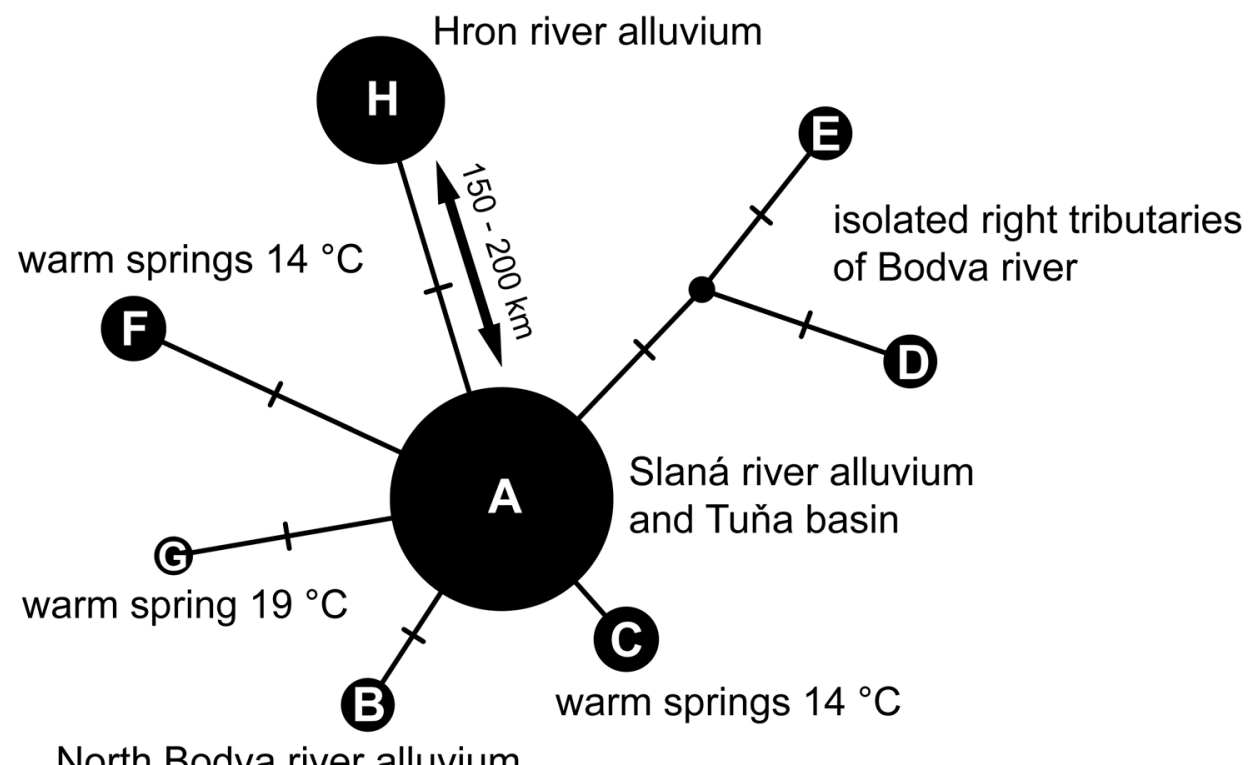

North Bodva river alluvium

Fig. 10. Statistical parsimony network of H. kissdalmae Erőss \& Petró, 2008 based on 16S rRNA. Haplotype circles A-H are proportional in size to the number of individuals with identical sequences. For comprehensive specimen information see Supp. file 1, Fig. S1. Crosslines and small circle represent non-sampled haplotypes. 
suggested that the animals were associated with the delicate net of roots and rootlets within the spring zone. We called this specific hypogean habitat phreatic rhizosphere (Jasinska et al. 1996; Grego in press) where the mollusks and crustaceans likely feed on the root exudates (Badri \& Vivanco 2009) or on the microbes supported by exudates or directly on live or decaying root tissue. The root exudates are probably a frequently underestimated hypogean food source considering that the trees are returning about $20-40 \%$ of the carbon fixed by photosynthesis to the soil microflora and mycorrhiza through exudates (Badri \& Vivanco 2009). The association of the species to the phreatic rhizosphere was on the one hand directly confirmed by higher numbers of living individuals collected in habitats with roots (e.g., wells or spring heads), and on the other hand by long term monitoring (2012-2021) of the spring Ladová Studña in the Driekyňa valley, Bystrica Highlands, Slovakia. The sampling was done according to Grego et al. (2017). We took 250-280 g of wet sediment at the spring head at each sampling. This yielded a relatively high and stable count of live individuals (20-35) as well as a stable ratio to empty shells (0.8-0.86) until the first selective tree cut in the forest in about $50 \mathrm{~m}$ around the spring zone in autumn 2013. Under these altered conditions the population of $\mathrm{H}$. kissdalmae declined (live individuals 12-20) and the population displayed a higher instability (ratio of live to empty shells $0.33-1.28$ ). After the entire deforestation of the spring zone in autumn 2014, the population rapidly decreased to 3-5 live individuals per sample with a marked increase of empty shells (43) and four years later, the population apparently disappeared and now even empty shells became scarce (Fig. 11). These observations strongly support the association of $H$. kissdalmae to the rhizosphere and the importance of the dendroflora surrounding the spring zone.

Distribution range, molecular data and the considerations about habitat suggest that the species disperses along the alluvial river and rivulet beds represented by the hyporheic zone and the phreatic rhizosphere. Most likely the species is widespread under the tree belts framing the rivers along the alluvium, but live individuals can only be collected in springs or wells associated to the alluvium. The narrow specialization

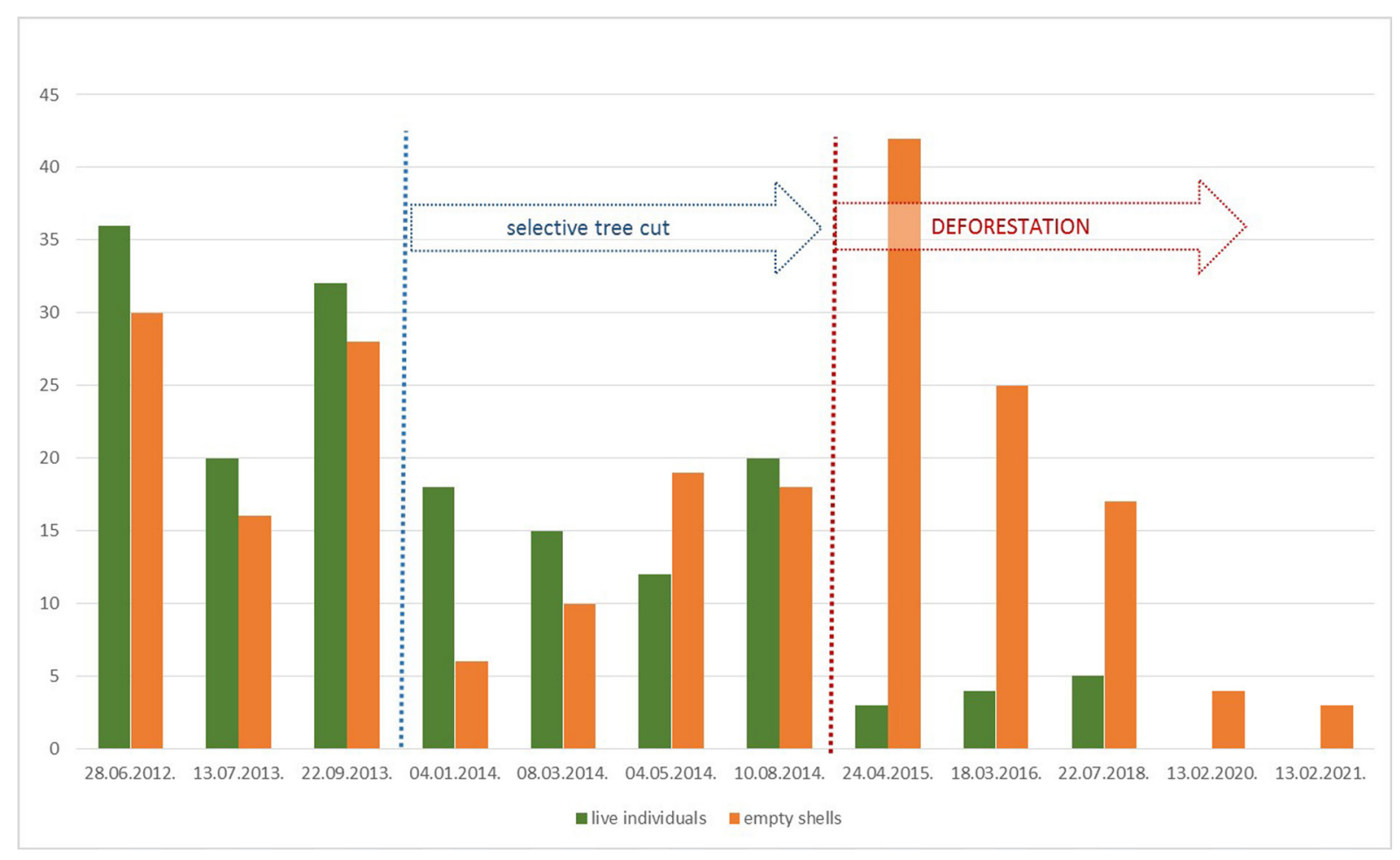

Fig. 11. Monitoring of H. kissdalmae Erőss \& Petró, 2008 in spring L'adová Studňa, Driekyňa Valley, Slovenská L’upča, Slovakia (locality 61 from Table 1) from 2012-2021. 
of H. kissdalmae to specific subterranean habitats makes it very sensitive to alterations of the habitat. The main threat is the deforestation of spring zones and river banks, which is frequently followed by artificial strengthening of the river banks or transformation of the river beds into artificial channels as well as building of dams and small power plants. This obviously leads to dramatic changes of the character of the hyporheic zone, including groundwater pollution.

\title{
Systematic descriptions
}

The quality of fixation of the material was fairly heterogeneous. Therefore, anatomical descriptions had to remain incomplete. Curiously, all live collected adult specimens were male. The single female was immature.

\author{
Phylum Mollusca Linnaeus, 1758 \\ Class Gastropoda Cuvier, 1795 \\ Subclass Caenogastropoda Cox, 1960 \\ Family Hydrobiidae Stimpson, 1865 \\ Genus Hauffenia Pollonera, 1898
}

Hauffenia lozekiana sp. nov. urn:1sid:zoobank.org:act:63FE4F3F-32A5-4F83-869F-C72B6E2D56AE

Figs 2, 5 71a-b, 12A-C, 13A-B, 14A, 15A-C, 17A-B, 18; Tables 3-4

\section{Diagnosis}

The combination of valvatiform shell with eventually detached peristome and an only initially sculptured embryonic shell, a thin, yellow operculum without peg-like structure in the nucleus and the massive, trapezoidal penis, whose left side is flattened, distinguishes H. lozekiana sp. nov. from all other congeneric species. Only three diagnostic positions of the COI alignment were of type 1, a single of type 3, and 107 of type 4 (Table 3). Uncorrected genetic distances to congeners ranged from 0.077 (H. kerschneri) to 0.133 (H. steffeki sp. nov.; see Supp. file 3).

\section{Etymology}

Hauffenia lozekiana sp. nov. is dedicated to Vojen Ložek (26 Jul. 1925-15 Aug. 2020), renowned and influential Czech malacologist and paleontologist, who contributed significantly to Quaternary malacostratigraphy, Czechoslovakian zoogeography of mollusks and was the first to discover the genus Hauffenia in Slovakia.

\section{Material examined}

Holotype (Fig. 12A-C)

SLOVAKIA - Bystrica Highlands, vicinity of Poniky/Oravce, Kalinovský prameň (Kalinovec); $48^{\circ} 42.027^{\prime} \mathrm{N}, 19^{\circ} 15.952^{\prime}$ E; alt. 482 m; 4 Jan. 2014; J. Grego leg.; karst spring; NHMW 113638. (Fig. 5 $71 \mathrm{a}-\mathrm{b})$

Paratypes (Fig. 13A-B)

SLOVAKIA - 5 specs; same collection data as for holotype; JG F1684 • 4 specs; same collection data as for holotype; NHMW $113639 \cdot 2$ specs; same collection data as for holotype; ZPE -2 specs; same collection data as for holotype; 25 Jan. 2014; HNHM 105307 - 2 specs; same collection data as for holotype; JG F1649 • 2 specs; same collection data as for holotype; 18 May 2017; JG F1650 • 4 specs; same collection data as for holotype; 2 Jul. 2020; JG F1886 2 specs; same collection data as for holotype; NMBE $569388 \cdot 2$ specs; same collection data as for holotype; SMF $363255 \cdot 2$ specs; same 
collection data as for holotype; SMOPAJ 1/2021 - 2 specs; same collection data as for holotype; ZMH $140884 \bullet 3$ specs; same collection data as for holotype; 21 Dec. 2020; JG F1887.

\section{Description}

Shell (Figs 12A-C, 13A-B, 14A; Table 4). Valvatiform, maximum height measured $1.03 \mathrm{~mm}$, maximum width $1.58 \mathrm{~mm}$, on average twice as wide as high, with up to 2.75 whorls, final part of last whorl may be detached, fairly variable in shape with a coefficient of variation of $13.31 \%$ for the height/ width ratio; embryonic shell with 1.1-1.2 whorls, first 0.75 whorls wrinkled, sculpture then fading to become smooth; aperture almost round only slightly higher than wide, prosocline, lip continuous, not thickened; umbilicus wide.

OPERCULUM. Thin, chitinous, yellow, almost circular with central nucleus, the latter without peg or peglike modification.

EXTERNAl FeATURes. Epidermis without pigment, no eye spots visible, tentacles without particular ciliation.

MANTLE CAVITy. 9 gill filaments $(\mathrm{N}=1)$, osphradium short, oval, behind middle of gill.

Digestive system (Figs 15A-C, 16). Radula with formula R 4-5 1 4-5/1 1, L 4-6 1 5-6. M1 23-29, M2 15-20 ( $\mathrm{N}=3)$; intestine forming a long loop in roof of mantle cavity, the loop is additionally coiled, its appearance seems to vary depending on the presence and number of fecal pellets.

Female genitalia. Not observed; the only live collected female specimen was subadult, hence, the distal genitalia were not yet developed.

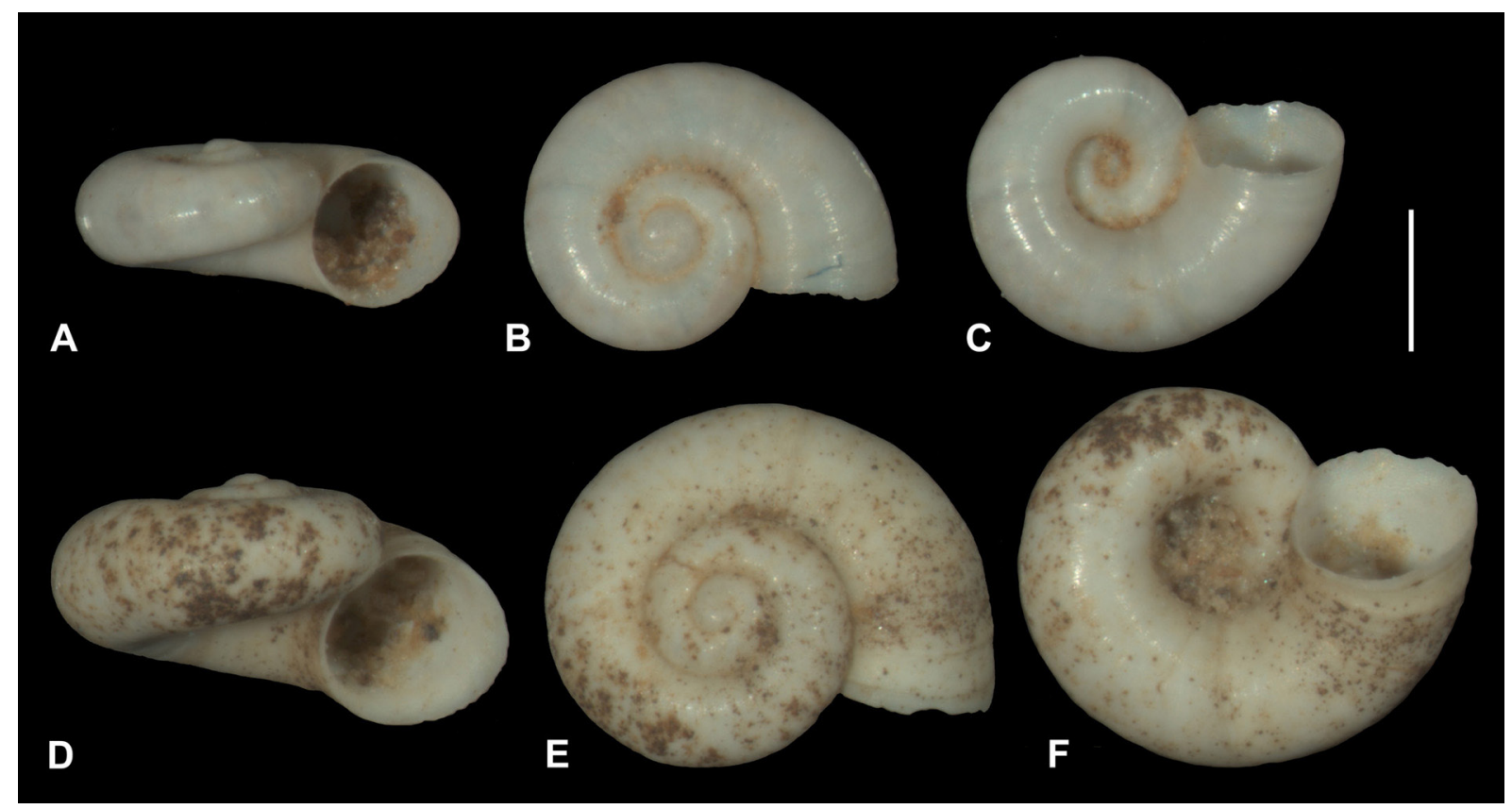

Fig. 12. Holotypes. A-C. H. lozekiana sp. nov. (NHMW 113638). D-E. H. steffeki sp. nov. (NHMW 113640). Scale bar $=500 \mu \mathrm{m}$. 
Male genitalia (Figs 17A-B, 18). Not observed except for kidney-shaped prostate and penis; penis massive, trapezoidal, left side flattened, small, brown, probably chitinous stylet anterior right near penial opening.

\section{Habitat}

The type locality is a small permanent karst spring emerging from the small karst massif of Drienok formed by Middle Triassic (Aegean-Ladinian) Wetterstein, Reifling and Gutenstein Limestones of the Silicikum Unit (Silica Nappe) at the contact zone to impermeable Early Triassic shales and sandstones of Szin and Bódvaszilas Members with a small discontinuous stripe of alluvial gravel at the bottom of the spring valley. The character of the type locality indicates the same habitat preference in the phreatic rhizosphere as discussed for $H$. kissdalmae.

\section{Distribution}

Known only from the type locality so far.

\section{Conservation}

There is only one known location and the area of occupancy is probably considerably smaller than $20 \mathrm{~km}^{2}$. The combination of the restricted range and the threat imposed by the apparent trend of logging in the area around the type locality qualify for a threat assessment of Vulnerable (VU, D2) according to the IUCN Standards and Petitions Committee (2019).

\section{Remarks}

The genetic distances of H. lozekiana sp. nov. from the more widespread H. kissdalmae and the Austrian species suggest that it is a relict probably from the earlier colonization of the Hron River Valley ca 4.5 Ma ago (see Discussion).

Hauffenia steffeki sp. nov. urn:1sid:zoobank.org:act:0637E21D-A9F8-429D-B025-2D3ED9E1E28E Figs 2, 5 72a-b, 12D-E, 13C-D, 14B, 15D-F, 16, 17C-E, 19; Tables 3-4

\section{Diagnosis}

Hauffenia steffeki sp. nov. is characterized by a valvatiform shell with eventually detached peristome and an only initially sculptured embryonic shell, a thin, orange operculum without peg-like structure in the nucleus and the massive, trapezoidal penis with a rounded lobe on the left side. There were nine diagnostic COI alignment positions of type 1, 13 of type 3, and 85 of type 4 (Table 3). Uncorrected genetic distances to congeners ranged from 0.108 [H. michleri (Kuščer, 1932)] to 0.141 (H. kissdalmae; see Supp. file 3).

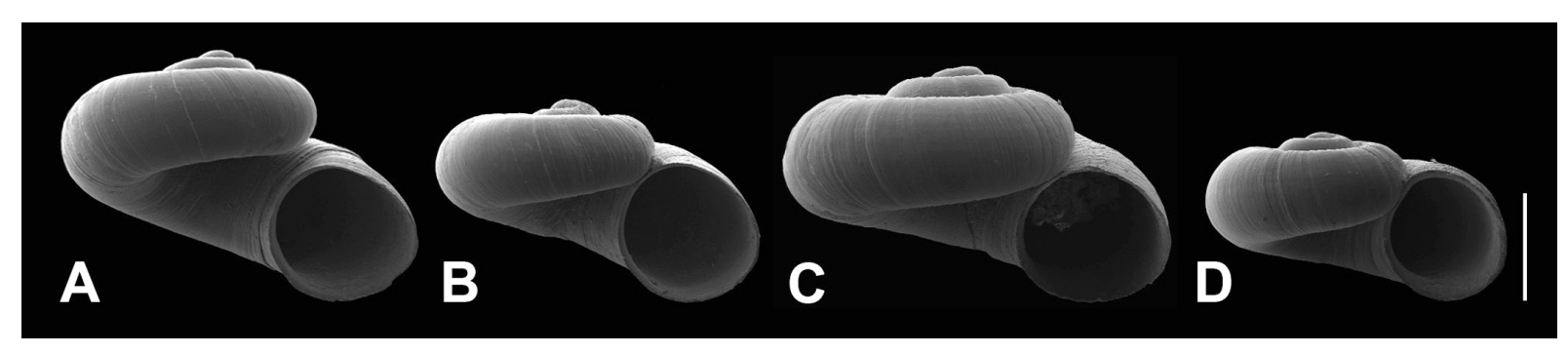

Fig. 13. Paratypes from type localities (SEM micrographs). A-B. H. lozekiana sp. nov. (NHMW 113639). C-D. H. steffeki sp. nov. (NHMW 113641). Scale bar $=500 \mu \mathrm{m}$. 


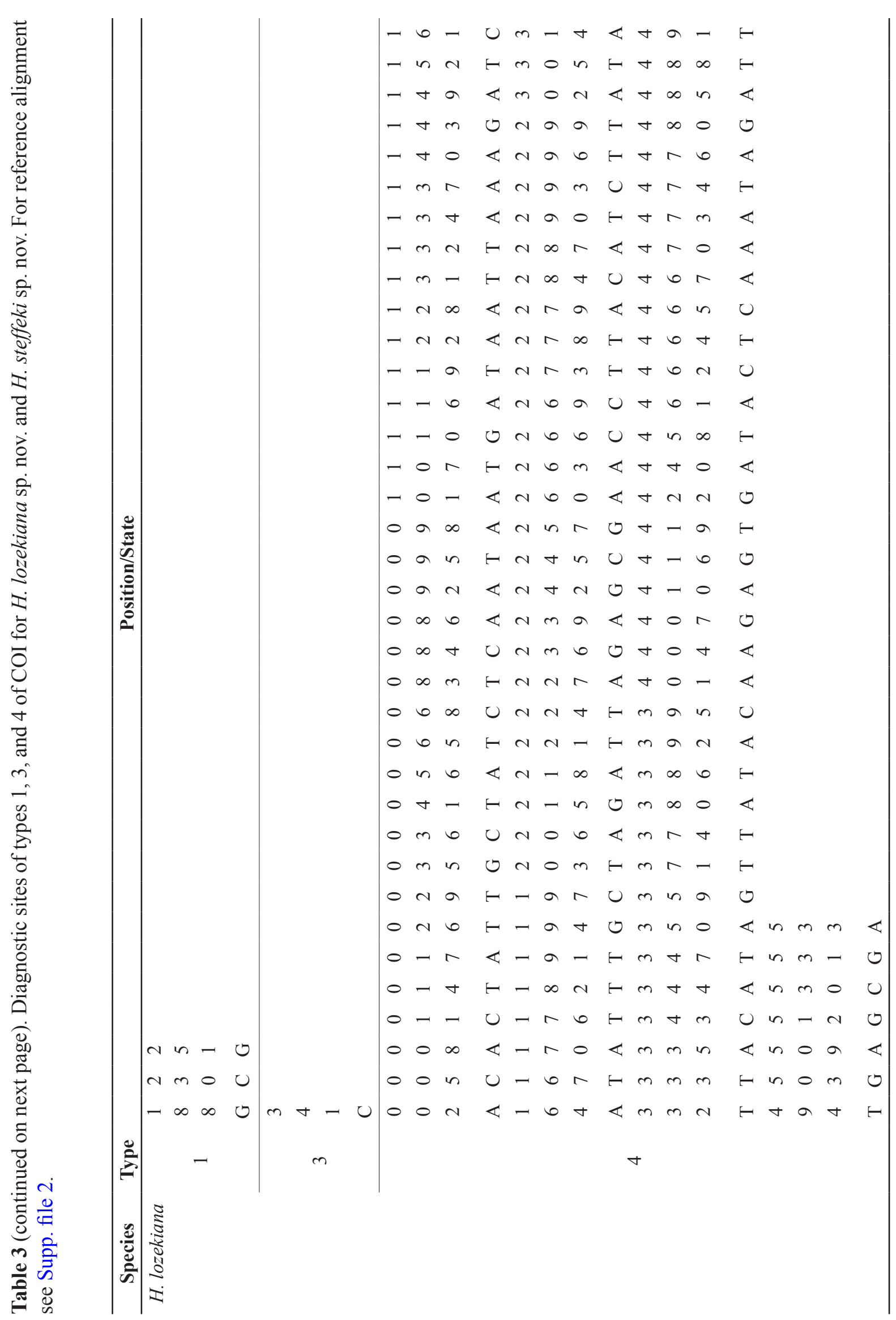




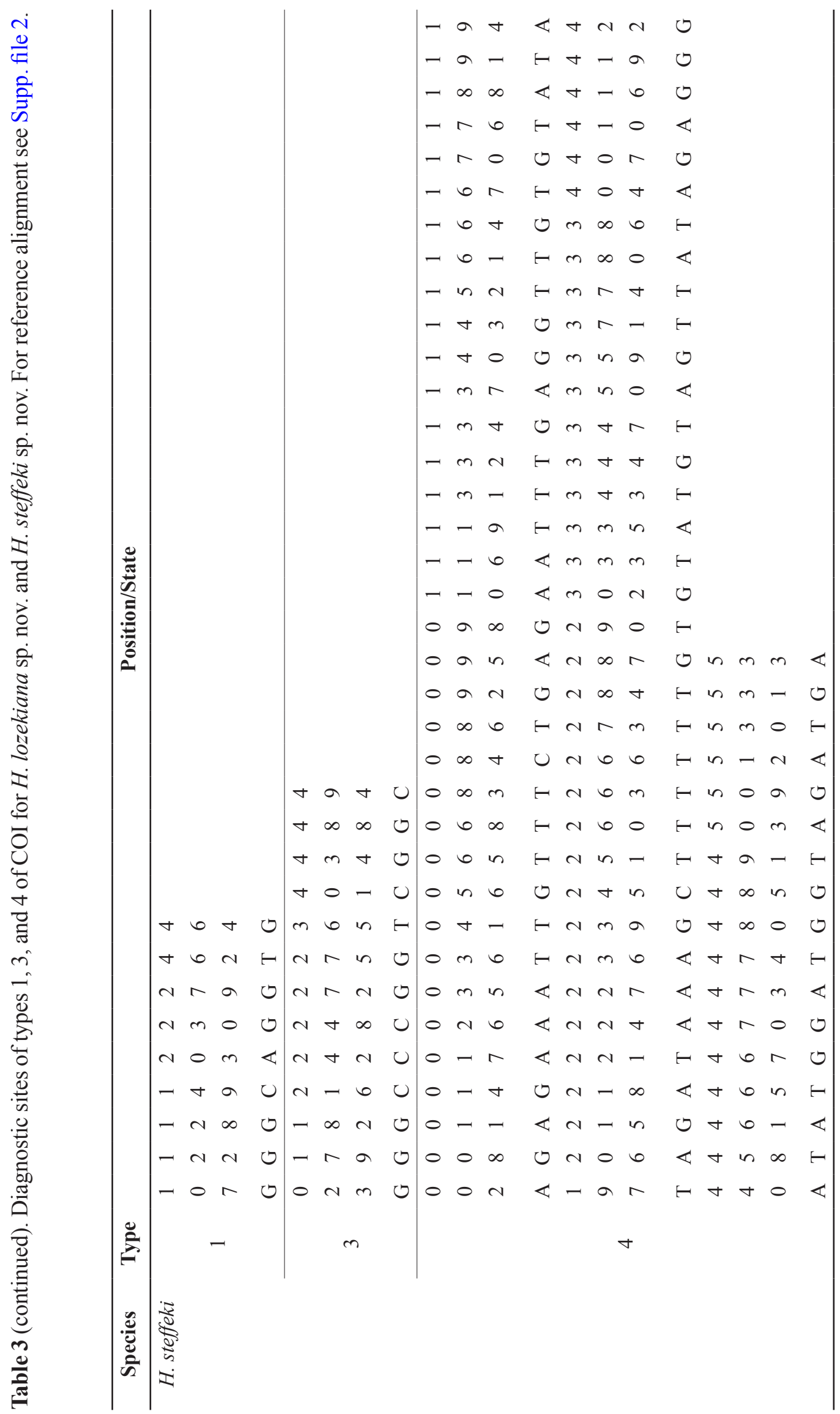




\section{Etymology}

Hauffenia steffeki sp. nov. is named after Jozef Šteffek (1 Jan. 1952-19 Apr. 2013), ever-helpful friend and unforgettable Slovak malacologist, initiator of the intensive field work dedicated to the genus Hauffenia in Slovakia.

\section{Material examined}

\section{Holotype (Fig. 12D-E)}

BOSNIA AND HERCEGOVINA - Bosnian Federation, Bihać district, Donji Kamengrad, 4 km W of Sanski Most; 4446.7682' N, 16³3.9859' E; alt. 228 m; 24 Mar. 2016; J. Grego, G. Jakab and B. Šmída leg.; spring and well in dry canyon; NHMW 113640. (Fig. 5 72a, b)

\section{Paratypes (Fig. 13C-D)}

BOSNIAAND HERCEGOVINA - Bosnian Federation - 13 specs; same collection data as for holotype; JG F0679 • 10 specs; same collection data as for holotype; NHMW $113641 \cdot 8$ specs; same collection data as for holotype; 4 Apr. 2015; J. Grego, M. Grego, R. Lohaj and B. Šmída leg.; JG F0473 • 10 specs; same collection data as for holotype; 24-25 Mar. 2016; J. Grego, M. Olšavský, G. Jakab and B. Šmída leg.; HNHM $105308 \cdot 33$ specs; same collection data as for holotype; JG F0561 • 10 specs; same collection data as for holotype; NMBE 569389 - 10 specs; same collection data as for holotype; SMF 363256 • 10 specs; same collection data as for holotype; SMOPAJ 2/2021 10 specs; same collection data as for holotype; ZMH 140885 - 35 specs; Bosanska Krajina, Sanski Most district, Dabarska Pećina, cave in Donji Dabar near Bankovići; 44²42.6' N, 16³8.31' E; alt. 173 m; 25 Mar. 2016; J. Grego, M. Olšavský, G. Jakab and B. Šmída leg; sand on cave river bottom; JG0565 - 68 specs; same collection data as for preceding; 15 Mar. 2017; J. Grego, G. Jakab and B. Šmída leg.; JG F0692 • 12 specs; Bihać district, Spring Krivina, Lušči Palanka-Miljevci, $400 \mathrm{~m}$ from village toward Sanski Most, at right side of road

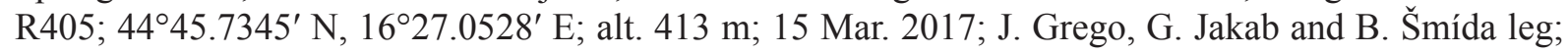

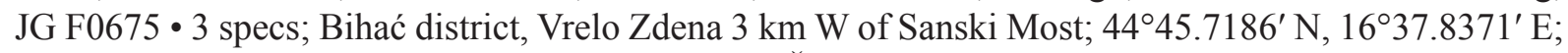
alt. 176 m; 15 Mar. 2017; J. Grego, G. Jakab and B. Šmída leg.; JG F1888 • 7 specs; Bihać district, Izvor Banovac between Gorice and Naprelie, left side of the road; $44^{\circ} 46.8065^{\prime} \mathrm{N}, 16^{\circ} 30.0365^{\prime} \mathrm{E}$; alt. $375 \mathrm{~m}$; 15 Mar. 2017; J. Grego, G. Jakab and B. Šmída leg.; JG F0668.
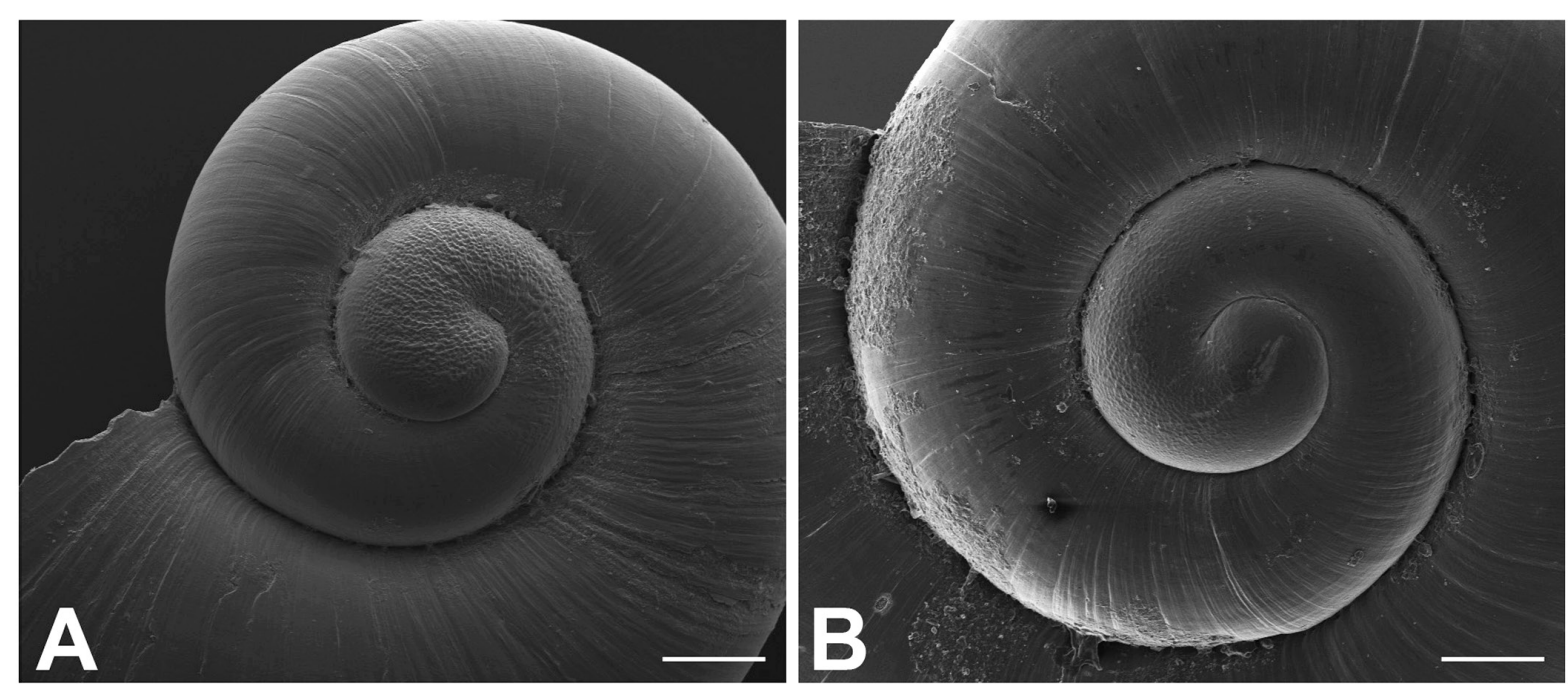

Fig. 14. Protoconchs (SEM micrographs). A. H. lozekiana sp. nov., paratype (NHMW 113639). B. H. steffeki sp. nov., paratype (NHMW 113641). Scale bars $=100 \mu \mathrm{m}$. 
Other material tentatively allocated to $\mathrm{H}$. steffeki

BOSNIA AND HERCEGOVINA - Bosnian Federation • 1 spec.; Bihać district, Bastaško Vrelo, 5 km W of Drvar; $44^{\circ} 23.584^{\prime}$ N, $16^{\circ} 19.572^{\prime}$ E; alt. 527 m; 15 Mar. 2017; J. Grego, G. Jakab and B. Šmída leg.; JG F 0743. - Republika Srpska • 7 specs; Donja Pećka, Izvor Sana; 44⒚0302' N, 1650.1773' E; alt. 446 m; 15 Mar. 2017; J. Grego, M. Olšavský, G. Jakab and B. Šmída leg.; sand on bank of river; JG F 0571/.
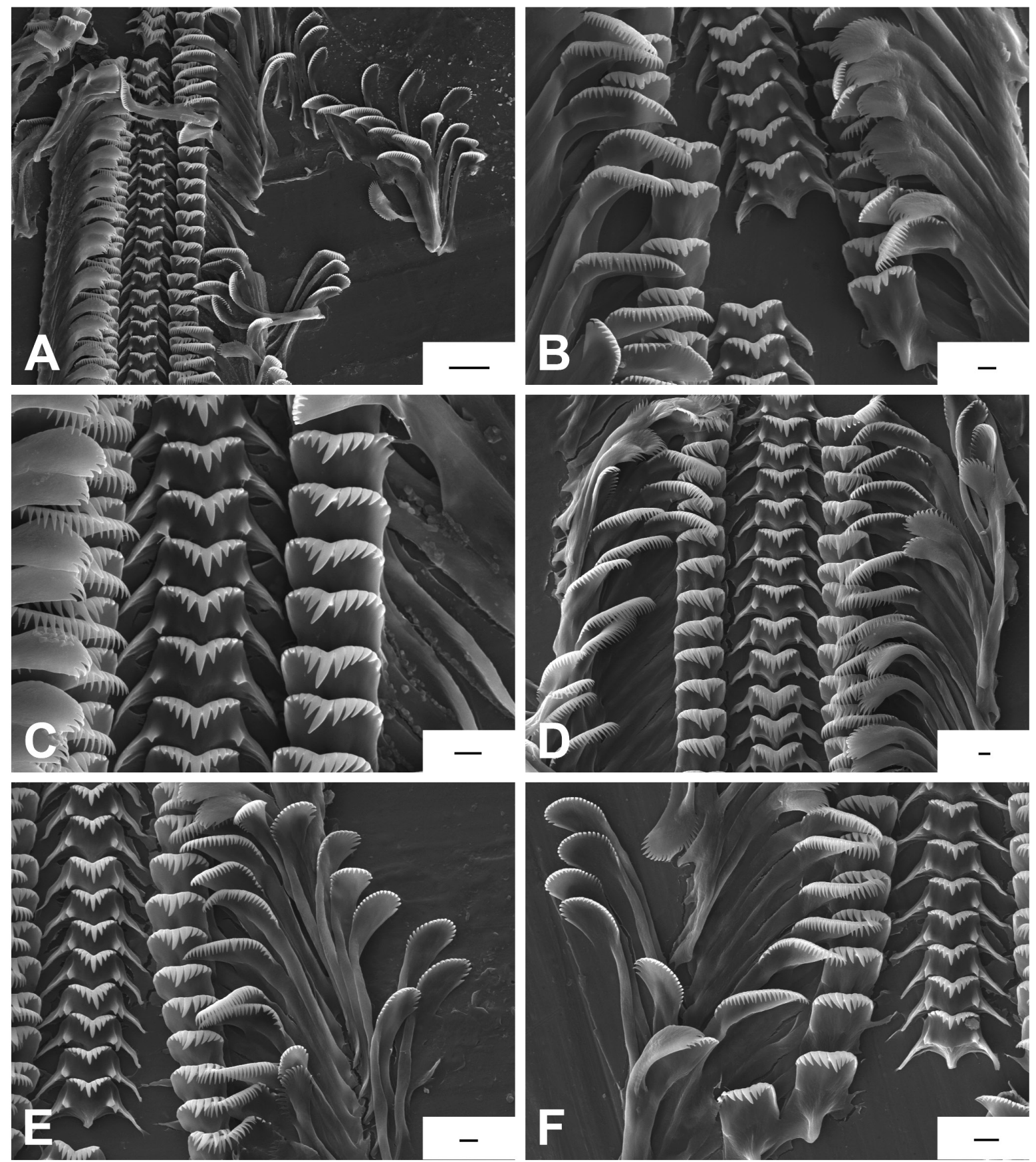

Fig. 15. Radulae (SEM micrographs). A-C. H. lozekiana sp. nov. D-F. H. steffeki sp. nov. D. Type locality. E-F. Spring Krivina (locality 74 from Table 1). Scale bars: A $=10 \mu \mathrm{m} ; \mathrm{B}-\mathrm{E}=2 \mu \mathrm{m} ; \mathrm{F}=3 \mu \mathrm{m}$. 
Table 4. Morphometrics of the new species. Abbreviations: $\mathrm{AH}=$ aperture height; $\mathrm{AW}=$ aperture width; $\mathrm{CV}=$ coefficient of variation corrected for unequal sample sizes; $\max =$ maximum; $\min =$ minimum; $\mathrm{SD}=$ standard deviation; $\mathrm{SH}=$ shell height; $\mathrm{SW}=$ shell width; $\mathrm{W}=$ number of whorls (to the nearest eighth). Measurements in $\mathrm{mm}$.

\begin{tabular}{|c|c|c|c|c|c|c|c|}
\hline Species & SH & SW & AH & AW & SH/SW & AH/AW & $\mathbf{W}$ \\
\hline \multicolumn{8}{|c|}{ H. lozekiana sp. nov. } \\
\hline \multicolumn{8}{|l|}{ Kalinovský } \\
\hline \multicolumn{8}{|l|}{$\mathrm{N}=16$} \\
\hline Holotype & 0.65 & 1.36 & 0.60 & 0.54 & 0.48 & 1.12 & 2.375 \\
\hline $\min$ & 0.58 & 1.10 & 0.49 & 0.47 & 0.47 & 0.94 & 2.125 \\
\hline $\max$ & 1.03 & 1.58 & 0.66 & 0.64 & 0.69 & 1.12 & 2.750 \\
\hline mean & 0.73 & 1.35 & 0.58 & 0.55 & 0.52 & 1.04 & 2.432 \\
\hline median & 0.68 & 1.34 & 0.60 & 0.54 & 0.49 & 1.04 & 2.375 \\
\hline $\mathrm{SD}$ & 0.12 & 0.14 & 0.05 & 0.06 & 0.07 & 0.05 & 0.197 \\
\hline $\mathrm{CV}$ & 16.87 & 10.27 & 8.75 & 10.22 & 13.31 & 4.44 & 8.802 \\
\hline \multicolumn{8}{|c|}{$\begin{array}{c}\text { H. steffeki sp. nov. } \\
\text { Donji } \\
\mathrm{N}=20\end{array}$} \\
\hline Holotype & 0.92 & 1.63 & 0.72 & 0.68 & 0.57 & 1.07 & 2.625 \\
\hline $\min$ & 0.69 & 1.40 & 0.58 & 0.54 & 0.45 & 1.00 & 2.250 \\
\hline $\max$ & 1.08 & 1.77 & 0.74 & 0.69 & 0.72 & 1.15 & 2.875 \\
\hline mean & 0.89 & 1.56 & 0.68 & 0.62 & 0.57 & 1.09 & 2.575 \\
\hline median & 0.88 & 1.54 & 0.69 & 0.64 & 0.56 & 1.10 & 2.625 \\
\hline $\mathrm{SD}$ & 0.11 & 0.10 & 0.05 & 0.05 & 0.07 & 0.03 & 0.148 \\
\hline $\mathrm{CV}$ & 12.38 & 6.73 & 7.18 & 7.70 & 12.87 & 3.14 & 5.837 \\
\hline \multicolumn{8}{|c|}{$\begin{array}{l}\text { H. steffeki sp. nov. } \\
\text { Dabarska Pećina } \\
\quad \mathrm{N}=20\end{array}$} \\
\hline $\min$ & 0.52 & 1.34 & 0.51 & 0.48 & 0.36 & 1.02 & 2.375 \\
\hline $\max$ & 0.69 & 1.54 & 0.61 & 0.55 & 0.47 & 1.13 & 2.625 \\
\hline mean & 0.61 & 1.45 & 0.55 & 0.52 & 0.42 & 1.07 & 2.544 \\
\hline median & 0.61 & 1.47 & 0.56 & 0.52 & 0.43 & 1.06 & 2.500 \\
\hline SD & 0.04 & 0.06 & 0.03 & 0.02 & 0.03 & 0.03 & 0.073 \\
\hline $\mathrm{CV}$ & 6.52 & 4.07 & 4.66 & 3.76 & 6.41 & 2.50 & 2.921 \\
\hline \multicolumn{8}{|c|}{$\begin{array}{l}\text { H. steffeki sp. nov. } \\
\text { Krivina } \\
\mathrm{N}=5\end{array}$} \\
\hline $\min$ & 0.56 & 1.06 & 0.47 & 0.43 & 0.49 & 1.04 & 2.125 \\
\hline $\max$ & 0.76 & 1.27 & 0.57 & 0.52 & 0.59 & 1.13 & 2.375 \\
\hline mean & 0.64 & 1.18 & 0.52 & 0.47 & 0.54 & 1.08 & 2.250 \\
\hline median & 0.62 & 1.21 & 0.53 & 0.48 & 0.54 & 1.08 & 2.250 \\
\hline SD & 0.07 & 0.10 & 0.05 & 0.04 & 0.07 & 0.06 & 0.177 \\
\hline $\mathrm{CV}$ & 11.88 & 8.55 & 9.39 & 7.98 & 8.47 & 2.97 & 6.320 \\
\hline
\end{tabular}




\section{Description}

SHELl (Figs 12D-E, 13C-D, 14B; Table 4). Valvatiform, maximum height measured at type locality $1.08 \mathrm{~mm}$, maximum width $1.77 \mathrm{~mm}$, with up to 2.875 whorls, on average twice as wide as high, considerably smaller in Krivina and Dabarska Pećina, there also flatter, final part of last whorl may be detached, fairly variable in shape with a coefficient of variation of $12.87 \%$ for the height/width ratio at the type locality, less pronounced at the other two localities where measurements have been taken; embryonic shell with 1.1-1.2 whorls, first 0.75 whorls faintly wrinkled, then smooth; aperture almost round only slightly higher than wide, ortho- or prosocline, lip continuous, not thickened; umbilicus wide.

OperCulum (Fig. 19). Thin, chitinous, orange, almost circular with central nucleus, the latter without peg or peg-like modification.

EXtERnAl FEATURES. Epidermis without pigment, no eye spots visible, tentacles without particular ciliation.

MantLe Cavity. 9-12 gill filaments ( $\mathrm{N}=2)$, osphradium short, oval, behind middle of gill.
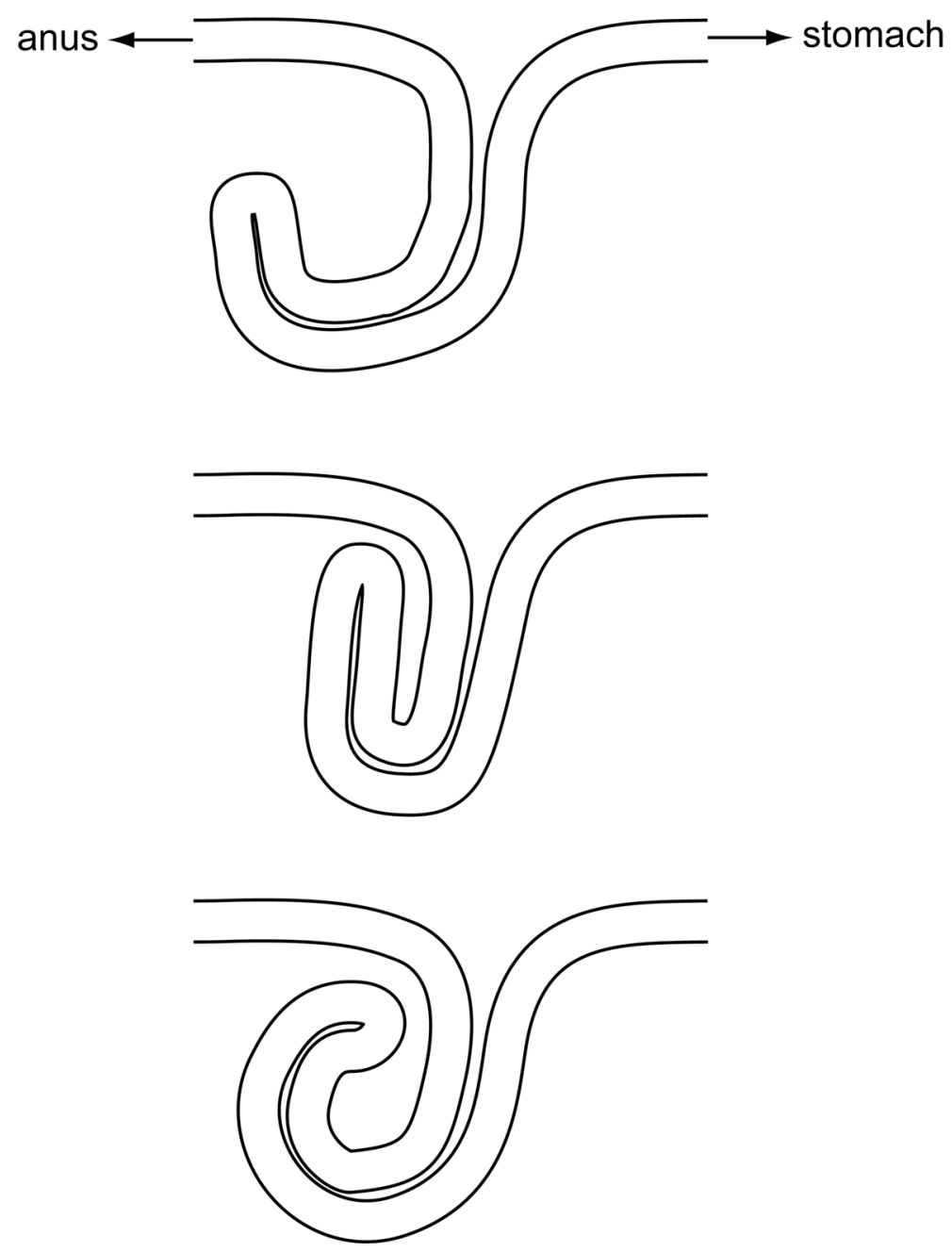

Fig. 16. Schematic representations of intestinal loop configurations. 
Digestive system (Figs 15D-F, 16). Radula with formula R 5-6 1 5-6/1 1, L 51 5, M1 22-24, M2 17 19 (Donji Kamengrad, N = 1), R 51 5/1-2 1-2, L 4-5 1 5, M1 22-26, M2 19-23 (spring Krivina, N = 2); intestine forming a long loop in roof of mantle cavity, the loop is additionally coiled, its appearance seems to vary depending on the presence and number of fecal pellets.

Female Genitalia. Not observed; all live collected specimens were male.

Male genitalia (Fig. 17C-E). Testis starting at least one whorl below apex, comprising ca 0.25 whorls, reaching stomach; prostate kidney shaped; penis massive, trapezoidal, with rounded lobe on left side, small, brown, probably chitinous stylet anterior right near penial opening.

\section{Habitat}

The type locality is a small well in a meadow in a dry valley west of Donji Kamengrad associated to a nearby karst spring at the north side of the valley. The Dabarska Pećina is a large river cave, one of the two main sources of the Dabar River (left tributary of the Sana River), draining the karst waters from the plateaus above the Jezernica basin through Bobijaško oko Estavella and numerous sinkholes. The other localities are rather smaller permanent karst springs and wells associated to small alluvial stripes with forested surroundings. These localities suggest a habitat preference for the phreatic rhizosphere as discussed for $\mathrm{H}$. kissdalmae. However, the live specimens were also found in sediment on the bottom of the cave which indicates also a wider subterranean distribution including open cave conduits in a similar
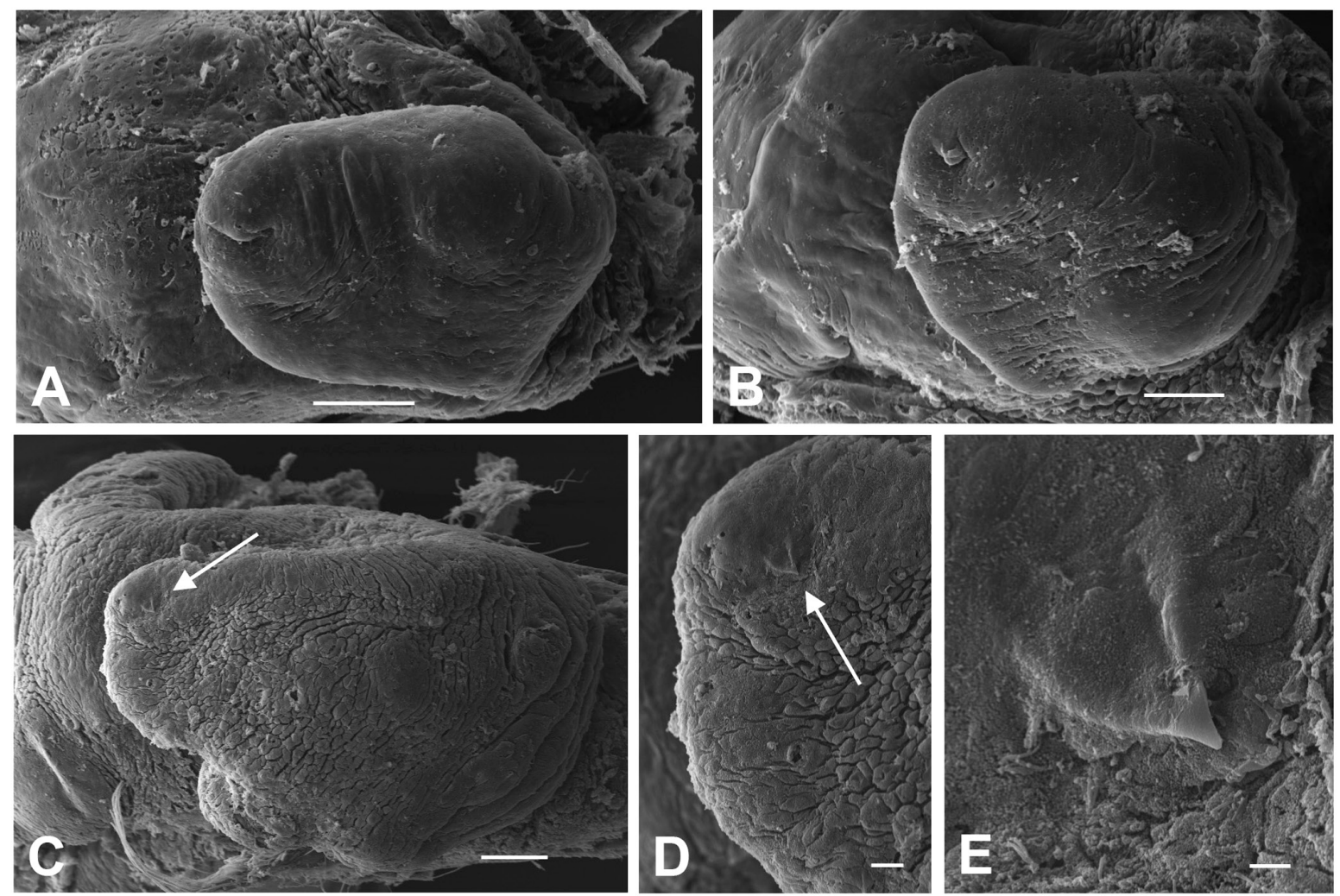

Fig. 17. Penes (SEM micrographs). A-B. H. lozekiana sp. nov. (different specimens). C-E. H. steffeki sp. nov. (one specimen). Arrow points at penial stylet, which is withdrawn in A and B. Scale bars: A-C = $50 \mu \mathrm{m} ; \mathrm{D}=10 \mu \mathrm{m} ; \mathrm{E}=2 \mu \mathrm{m}$. 
way as suggested for the species of Hauffenia from Slovenia, Italy and Croatia (Bole 1970; Bole \& Velkovrh 1987; Rysiewska et al. 2016).

\section{Distribution}

Known only from the type locality and four nearby localities at Bosanska Krajina west and northwest of Sanski Most.

\section{Conservation}

The new species is known from only five locations and it is very probable that the area of occupancy is smaller than $20 \mathrm{~km}^{2}$. At this stage, we could not identify any plausible threats so that $H$. steffeki sp. nov. is assessed as Near Threatened (NT; IUCN Standards and Petitions Committee 2019).

\section{Remarks}

Hauffenia steffeki sp. nov. extends the distribution of the genus further south and is genetically/ phylogenetically distinct from all other species for which sequence information is available. It is likely that the species has a wider distribution in springs draining to and in the alluvium of the Sana River up to its source. In the type locality, it is syntopic with Lanzaia bosnica Bole, 1970 and in Dabarska Pećina with stygobiotic gastropods including Dabriana bosniaca Radoman, 1974, Lanzaia bosnica Bole, 1970 and Paladilhiopsis blihensis (Glöer \& Grego, 2015) (Glöer \& Grego 2015).

\section{Discussion}

The phylogenetic analyses based on different DNA markers and their combinations did not converge to an unambiguous topology, node support remained insignificant for many splits. However, a few important insights into the evolution of Hauffenia can safely be inferred. 1) The genus probably had its origin in the Middle or Late Miocene; 2) most speciation events occurred in the Pliocene; 3) within species differentiation is young and happened during the Pleistocene; and 4) there appear to be two

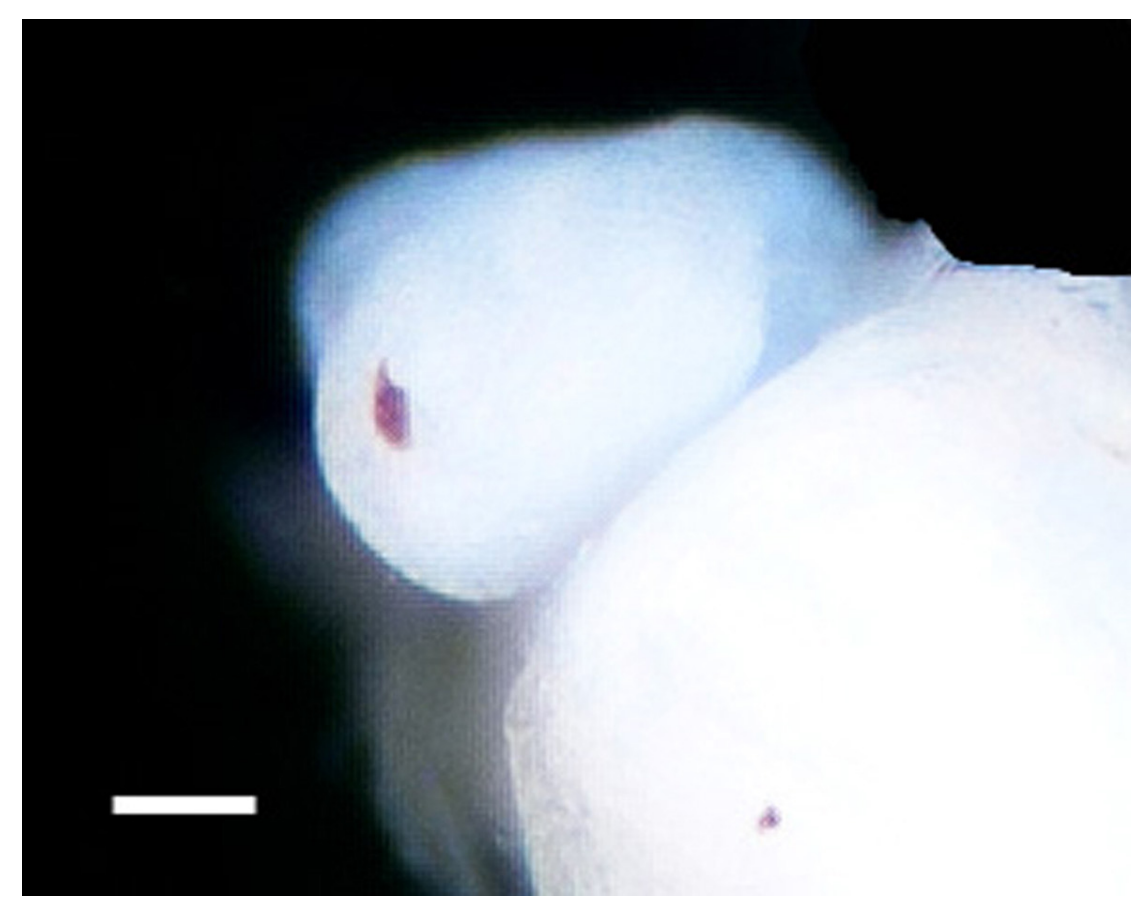

Fig. 18. Penis of H. lozekiana sp. nov. Frontal view showing stylet. Scale bar $=50 \mu \mathrm{m}$. 
major groups, a radiation on the Balkans and into NE Italy, and a northern group extending from central Austria to Hungary and Slovakia. It is unclear, though, whether these groups are sister clades or whether the former is paraphyletic with respect to the latter.

Based on the time tree (Fig. 9) - theoretically considered superior to conventional analyses requiring an outgroup for rooting by some authors (Drummond et al. 2007) - and paleogeographic considerations as well as considering the above caveats, we developed the following - admittedly speculative - scenario for the evolution of Hauffenia (Fig. 20). Hauffenia probably had a Dinaric origin and spread northwards in the Upper Miocene about $10 \mathrm{Ma}$, when the Pannonian Sea had formed as an isolated continental lake, a remnant of the Paratethys, after the closure of the straits towards Bavaria, Đerdap Valley, Preševo Valley, and Slovenia (Kázmér 1990; Magyar et al. 1999). Especially closing the Slovenian strait (Ivančič et al. 2018) opened the dispersal path towards what are now Slovenia and NE Italy. Similar to the extant species of the region [H. erythropomatia, H. media Bole, 1961, H. michleri, H. subcarinata Bole \& Velkovrh, 1987, H. subpiscinalis (Kuščer, 1932), H. tellinii (Pollonera, 1898), H. wagneri (Kuščer, 1928)], the ancestral populations likely dwelled in karstic and cave conduits (Falniowski \& Szarowska 2015). The Pannonian Sea gradually shrunk in surface and the salinity dropped due to discharge of larger rivers and alluvial deposits from the north. The sea turned into a freshwater lake (Uhrin 2011). Ancestral populations of Hauffenia now possibly adapted to and spread into alluvial interstices with penetrating tree roots. The hyporheic zone with its phreatic rhizosphere thus provided dispersal possibilities for colonizing the extensive alluvia at the NW banks of the Pannonian Lake (Sümeghy 1955; Somogyi 1961; Borsy 1989). This way, Hauffenia successfully colonized the Danube valley as well as the north-eastern Alps in what is now eastern Austria about $8 \mathrm{Ma}$. As the Pannonian Lake further contracted to become the Slavonian Lake (Paludina Lake) 5.5 Ma (Magyar et al. 1999; Rundić et al. 2016), more rivers drained the NE part of the Pannonian Basin opening further dispersal paths along Paleo-Ipel' (Ipoly), PaleoSlaná (Sajó) and Paleo-Bódva Rivers (Mezősi 2015) towards the now Slovak/Aggtelek Karst limestone formation founding eventually $H$. kissdalmae. The ancestor of $H$. lozekiana sp. nov. probably diverged

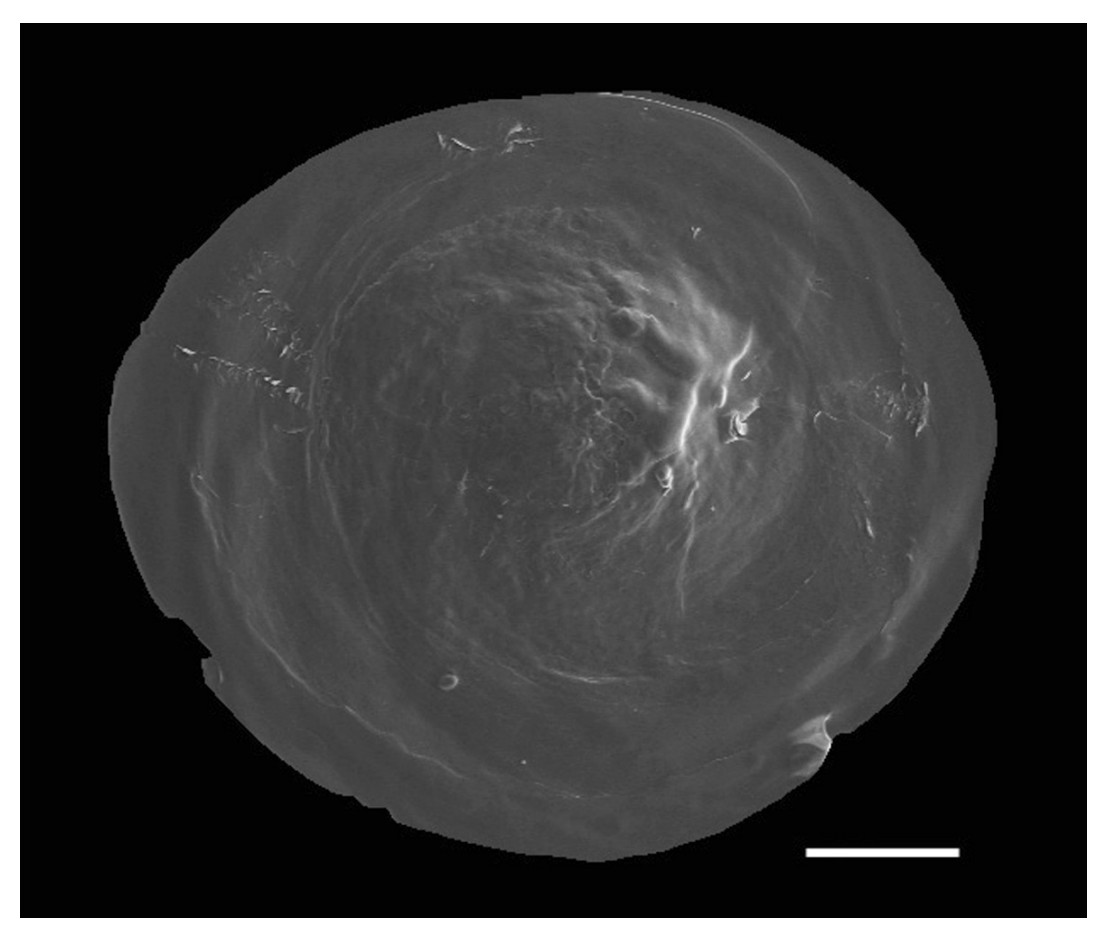

Fig. 19. Operculum of $H$. steffeki sp. nov., from type locality; internal side. Scale bar $=100 \mu \mathrm{m}$. 
from the lineage moving northwards towards today's Austria through the Paleo-Danube and Paleo-Hron River alluvium about 4.5 Ma. About 2 Ma the ancestral population of H. kissdalmae colonized the Paleo-Ipel' (Ipoly) alluvium and the eastern foothills of the Börzsöny Mountains (today, the Ipel' River is situated in the northern and western foothills) and further dispersed through the Rimava River Basin to the Slaná (Sajó) Valley at about 1.5 Ma. Dispersal into the Hron Valley up to Nemecká was only enabled later. After the elevation of the Western Pannonian Basin the Paleo-Danube significantly changed its direction and intersected into the Paleo-Ipel' (Ipoly) Valley by the "Visegrad Break-Through" (Visegrádi áttörés) (Gábris 1994; Karátson 2014), hence connected the alluvia of Hron and Ipel' at about 2 Ma. The Hron Valley fully opened for colonization about $0.7-1$ Ma when the Paleo-Ipel' River changed its flow direction towards the northern and western foothills of the Börzsöny Mountains, coming to its present-day position adjacent to the Hron River (Mike 1991) and the alluvial cross-connection of both rivers became more intensive. At that time (about $1 \mathrm{Ma}$ ), the ancestral populations of $H$. lozekiana sp. nov. dwelling in the Hron Valley were probably already declining and fragmented due to neovolcanic activity over the past few Ma. Several lava flows reached the Hron valley and likely influenced the water

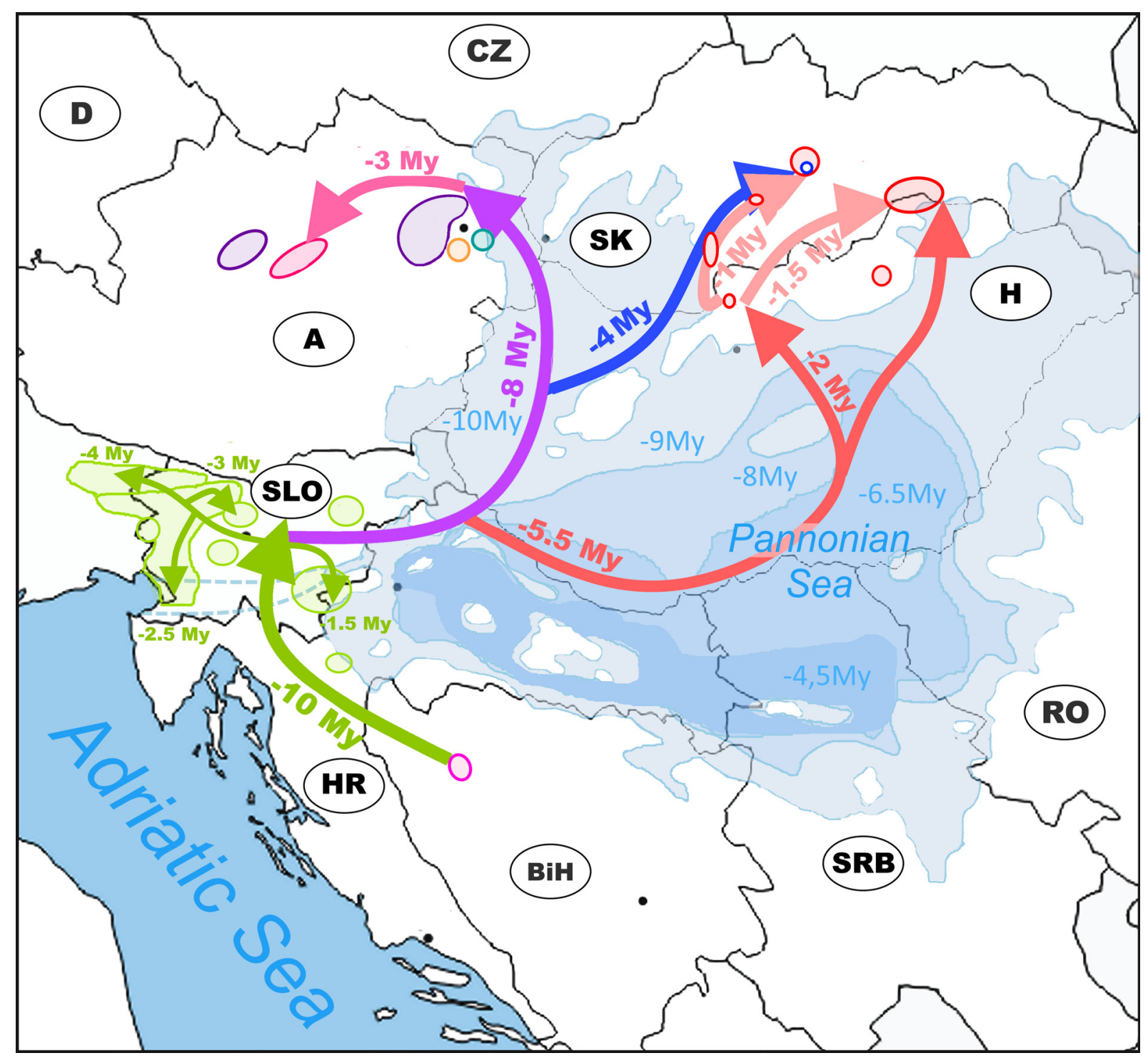

Fig. 20. Scenario of evolutionary diversification of Hauffenia Pollonera, 1898. 
quality (Šimon 2000). Thus the more recent invasion of $H$. kissdalmae into the Hron Valley resulted in a successful colonization of former H. lozekiana sp. nov. habitats. The only known extant population of H. lozekiana sp. nov. has certainly to be seen as a relict.

The Miocene origin coincides with the oldest fossils that have been attributed to Hauffenia, although their ages seem to predate the above scenario (in chronological order): H. mandici Neubauer \& Harzhauser, 2014, early Langhian (Badenian), Rein Basin in the eastern foothills of the Alps of Austria (Harzhauser et al. 2014); H. sarmatica (Papp, 1954), Hauffenia sp. 1 and Hauffenia sp. 2, Vienna Basin and Weinviertel in eastern Austria (Papp 1954; Reischütz 2000); Hauffenia sp., Tortonian (Pannonian), Kötese at Lake Balaton in Hungary (Bandel 2010), ?Hauffenia sp., upper Tortonian (Maeotian), Ukraine (Anistratenko \& Anistratenko 2009). However, as already mentioned, fossil hydrobiids can rarely be attributed to an extant genus with certainty due to their poverty in shell characters and the high degree of convergence. Most of the above authors discussed these caveats. At least for the Austrian and Hungarian findings the allocation to Hauffenia may be supported by the fact that today no other valvatiform genus occurs there. But ultimately, our knowledge will not go beyond the coincidence of the occurrence of Hauffenia-like Miocene fossils in the range of contemporaneous species and the temporal inferences based on our time-tree. Regarding the slight temporal mismatch of fossil ages and our above evolutionary scenario we have also to recall that the time estimates in the tree come with considerable highest posterior density intervals, i.e., uncertainties (Fig. 9).

The extension of the occurrence of $H$. wienerwaldensis also west of the range of $H$. kerschneri was surprising (Haase 1992, 1993) but well substantiated by genetic and morphological (operculum, penis) data. Whether the range of $H$. wienerwaldensis is continuous - e.g., along the southern tributaries of the Danube - or disjunct, i.e., interrupted by H. kerschneri (see also Haase 1993 for further localities toward the east) is premature to judge. Clearly, Hauffenia has to be targeted in Austria in a similar systematic and thorough fashion as was done for $H$. kissdalmae. This would also include recollecting $H$. danubialis (Haase, 1993) and H. nesemanni Reischütz \& Reischütz, 2006 in order to confirm their status as separate species (type localities given in Fig. 3). The penial morphology of the former appears to be unique, indeed (Haase 1993). However, H. nesemanni has only been described based on shell morphology and is known from a single locality in the southern Vienna Basin (Reischütz \& Reischütz 2006). Looking at the morphological variation encountered within both here newly described species (Figs 12-13) at least questions whether shell morphology is diagnostic in Hauffenia. Clearly, anatomical and DNA sequence data are needed here.

Our analyses confirm Falniowski \& Szarowska (2015) and Rysiewska et al. (2017) that H. michleri is a valid species and should not be synonymized with $H$. tellinii as proposed by Bodon et al. (2001). Both sequences KT236156 and KY087861 are still listed as H. tellinii in GenBank. The possibility that the two sequences attributed to $H$. erythropomatia represent in fact two different species has already been suggested by Rysiewska et al. (2017) because of their genetic disparity reflected in the disjunct positions in the phylogenetic trees (Fig. 9; Supp. file 1).

\section{Acknowledgments}

We thank Maroš Grego (Horná Mičiná, Slovakia), Roman Lohaj (Pezinok, Slovakia), Gabriel Jakab (Plešivec, Slovakia), and Branislav Šmída (Bratislava, Slovakia) for support during the speleological field trips to Bosnia and Hercegovina as well as Brian Lewarne from the Devon Karst Research Society (Plymouth, UK) and to the team of the "Proteus Project in R. Bosnia \& Hercegovina" for supporting our field research and for valuable discussions about the local geology and hydrology. Éva Szabari (Pécel, Hungary) was involved in collecting in the Bükk mountains. Sampling in the Slovak Karst was carried out during the monitoring phase of the project "Preparation and implementation of species and biotope monitoring with improvement of the public information system" supported by State Environmental 
Protection of the Slovak Republic and co-financed by the European Regional Development Fund in the framework of the "Operative Program-Environment". Collecting in the Aggtelek Karst (Hungary) was supported by the Aggtelek National Park Directorate. Austrian samples were provided by Anita Eschner, Luise Kruckenhauser (Natural History Museum of Vienna), Erhard Christian, Otto Moog (both Vienna), Alexander Reischütz (Horn), and Erich Weigand (Molln). We thank Thomas Neubauer (Gießen) for providing literature on fossil Hauffenia. We are particularly grateful to Silke Fregin, technician in Greifswald, for the DNA lab work. The SEM was operated by Stefan Bock at the Imaging Centre of the University of Greifswald. An earlier version of the manuscript has benefitted from comments by the editor Thierry Backeljau, Alexander Reischütz, and two anonymous reviewers.

\section{References}

Angelov A. 1967. Horatia (Hauffenia) lucidulus n. sp., ein neuer Vertreter der Molluskenfauna Bulgariens. Archiv für Molluskenkunde 96: 145-148.

Anistratenko O.Y. \& Anistratenko V.V. 2009. A problem of taxonomy of Maeotian gastropod mollusks "Skeneopsis planorbis". Collection of scientific works of the Institute of Geological Sciences of the NAS of Ukraine 2: 351-353, 494-495. https://doi.org/10.30836/igs.2522-9753.2009.148138

Badri D.V. \& Vivanco J.M. 2009. Regulation and function of root exudates. Plant, Cell \& Environment 32: 666-681. https://doi.org/10.1111/j.1365-3040.2009.01926.x

Bandel K. 2010. Valvatiform gastropoda (Heterostropha and Caenogastropoda) from the Paratethys Basin compared to living relatives, with description of several new genera and species. Freiberger Forschungshefte C 536, Paläontologie, Stratigraphie, Fazies 18: 91-155.

Barco A., Raupach M.J., Laakmann S., Neumann H. \& Knebelsberger T. 2016. Identification of North Sea molluscs with DNA barcoding. Molecular Ecology Resources 16: 288-297.

https://doi.org/10.1111/1755-0998.12440

Bodon M., Manganelli G. \& Giusti F. 2001. A survey of the European valvatiform hydrobiid genera, with special reference to Hauffenia Pollonera, 1898 (Gastropoda: Hydrobiidae). Malacologia 43: 103-215.

Bole J. 1970. Prispevek k poznavanju anatomije in taksonomije podzemeljskih hidrobiid (Gastropoda, Prosobranchia). Razprave IV. Razreda SAZU 13: 85-111.

Bole J. \& Velkovrh F. 1987. Nove vrste podzemeljskih polzev Jugolsavije. Razprave IV. Razreda SAZU 28: 69-83.

Borsy Z. 1989. Az Alföld hordalékkúpjainak negyedidőszaki fejlődéstörténete. Földrajzi Értesítő 38 (3-4): 211-224.

Bouckaert R., Vaughan T.G., Barido-Sottani J., Duchêne S., Fourment M., Gavryushkina A., Heled J., Jones G., Kühnert D., De Maio N., Matschiner M., Mendes F.K., Müller N.F., Ogilvie H.A., du Plessis L., Popinga A., Rambaut A., Rasmussen D., Siveroni I., Suchard M.A., Wu C.-H., Xie D., Zhang C., Stadler T. \& Drummond A.J., 2019. BEAST 2.5: an advanced software platform for Bayesian evolutionary analysis. PLoS Computational Biology 15: e1006650.

https://doi.org/10.1371/journal.pcbi. 1006650

Čiliak M. \& Šteffek J. 2013. Faunisticky významné druhy mäkkýšov z náplavov rieky Hron. Folia faunistica Slovaca 18: 81-89.

Clark S., Miller A. \& Ponder W.F. 2003. Revision of the snail genus Austropyrgus (Gastropoda, Hydrobiidae): a morphostatic radiation of freshwater gastropods in southeastern Australia. Records of the Australian Museum, Supplement 28: 1-109. https://doi.org/10.3853/j.0812-7387.28.2003.1377 
Clement M., Snell Q., Walke P., Posada D. \& Crandall K. 2002. TCS: estimating gene genealogies. Proceedings of the $16^{\text {th }}$ International Parallel Distribution Processes Symposium 2: 184. https://doi.org/10.1109/IPDPS.2002.1016585

Darriba D., Taboada G.L., Doallo R. \& Posada D. 2012. jModelTest 2: more models, new heuristics and parallel computing. Nature Methods 9: 772. https://doi.org/10.1038/nmeth.2109

Davis G.M. 1979. The origin and evolution of the gastropod family Pomatiopsidae, with emphasis on the Mekong River Triculinae. Monographs of the Academy of Natural Sciences of Philadelphia 20: $1-120$.

Delicado D., Arconada B., Aguado A. \& Ramos M.A. 2019. Multilocus phylogeny, species delimitation and biogeography of Iberian valvatiform springsnails (Caenogastropoda: Hydrobiidae), with the description of a new genus. Zoological Journal of the Linnean Society 186: 892-914.

https://doi.org/10.1093/zoolinnean/zly093

Delicado D., Pešić V. \& Ramos M.A. 2021. Arganiella Giusti \& Pezzoli, 1980 (Caenogastropoda: Truncatelloidea: Hydrobiidae): a widespread genus or several narrow-range endemic genera? European Journal of Taxonomy 750: 140-155. https://doi.org/10.5852/ejt.2021.750.1369

Drummond A.J., Ho S.Y.W., Philips M.J. \& Rambaut A. 2007. Relaxed phylogenetics and dating with confidence. PLoS Biology 4: e88. https://doi.org/10.1371/journal.pbio.0040088

Eröss Z.P. \& Petró E. 2008. A new species of the valvatiform hyrobiid genus Hauffenia from Hungary (Mollusca: Caenogastropoda: Hydrobiidae). Acta Zoologica Academiae Scientiarum Hungaricae 54: 159-167.

Falniowski A. \& Szarowska M. 2015. Species distinctness of Hauffenia michleri (Kuščer, 1931) (Caenogastropoda: Truncatelloidea: Hydrobiidae). Folia Malacologica 23: 193-195.

https://doi.org/10.12657/folmal.023.016

Gábris G. 1994. Pleistocene evolution of the Danube in the Carpathian Basin. Terra Nova 6: 495-501. https://doi.org/10.1111/j.1365-3121.1994.tb00893.x

Georgiev D. 2013. Localities of valvatiform hydrobiids (Gastropoda: Hydrobiidae) in Bulgaria. ZooNotes 43: 1-4.

Gittenberger E., Piel. W.H. \& Groenenberg D.S.J. 2004. The Pleistocene glaciations and the evolutionary history of the polytypic snail species Arianta arbustorum (Gastropoda, Pulmonata, Helicidae). Molecular Phylogenetics and Evolution 30: 64-73. https://doi.org/10.1016/S1055-7903(03)00182-9

Glöer P. \& Grego J. 2015. New subterranean freshwater molluscs from Bosnia \& Hercegovina (Mollusca: Hydrobiidae). Ecologica Montenegrina 2: 307-314. https://doi.org/10.37828/em.2015.2.37

Grego J. in press. Chapter 4: Mollusca. In: Wynne J. (ed.) Diversity and Speciation of Subterranean Fauna. Johns Hopkins University Press, Baltimore, Maryland, USA.

Grego J. \& Šteffek J. 2010. Ulitníky podzemného druhu Hauffenia sp. vo vyvieračkách Plešiveckej planiny. In: Stankovič J., Cílek V. \& Schmelzová R. (eds) Plešivecká planina: 150-152. Slovenská Speleologická Spoločnost', Liptovský Mikuláš.

Grego J., Glöer P., Erőss Z.P. \& Fehér Z. 2017. Six new subterranean freshwater gastropod species from northern Albania and some new records from Albania and Kosovo (Mollusca, Gastropoda, Moitessieriidae and Hydrobiidae). Subterranean Biology 23: 85-107. https://doi.org/10.3897/subtbiol.23.14930

Haase M. 1992. A new, stygobiont, valvatiform, hydrobiid gastropod from Austria (Caenogastropoda: Hydrobiidae). Journal of Molluscan Studies 58: 207-214. https://doi.org/10.1093/mollus/58.2.207 
Haase M. 1993. Hauffenia kerschneri (Zimmermann 1930): zwei Arten zweier Gattungen (Caenogastropoda: Hydrobiidae). Archiv für Molluskenkunde 121: 91-109.

https://doi.org/10.1127/arch.moll/121/1992/91

Haase M. 2008. The radiation of hydrobiid gastropods in New Zealand: a revision including the description of new species based on morphology and mtDNA sequence information. Systematics and Biodiversity 6: 99-159. https://doi.org/10.1017/S1477200007002630

Haase M., Misof B., Wirth T., Baminger H. \& Baur B. 2003. Mitochondrial differentiation in a polymorphic land snail: evidence for Pleistocene survival within the boundaries of permafrost. Journal of Evolutionary Biology 16: 415-428. https://doi.org/10.1046/j.1420-9101.2003.00542.x

Haase M., Marshall B.A. \& Hogg I. 2007. Disentangling causes of disjunction on the South Island of New Zealand: the Alpine fault hypothesis of vicariance revisited. Biological Journal of the Linnean Society 91: 361-374. https://doi.org/10.1111/j.1095-8312.2007.00801.x

Haase M., Meng S. \& Horsák M. 2021. Tracking parallel adaptation of shell morphology through geological times in the land snail genus Pupilla (Gastropoda: Stylommatophora: Pupillidae). Zoological Journal of the Linnean Society 191: 720-747. https://doi.org/10.1093/zoolinnean/zlaa057

Hall T.A. 1999. BioEdit: a user-friendly biological sequence alignment editor and analysis program for Windows 95/98/NT. Nucleic Acids Symposium Series 41: 95-98.

Harzhauser M., Neubauer T.A., Gross M. \& Binder H. 2014. The early Middle Miocene mollusc fauna of Lake Rein (Eastern Alps, Austria). Palaeontographica, Abteilung A: Palaeozoology - Stratigraphy 302: 1-71. https://doi.org/10.1127/pala/302/2013/1

Hershler R. \& Ponder W.F. 1998. A review of morphological characters of hydrobioid snails. Smithsonian Contributions to Zoology 600: 1-55. https://doi.org/10.5479/si.00810282.600

IUCN Standards and Petitions Committee. 2019. Guidelines for Using the IUCN Red List Categories and Criteria. Version 14. Prepared by the Standards and Petitions Committee. Available from http://www.iucnredlist.org/documents/RedListGuidelines.pdf [accessed 12 Jun. 2021].

Ivančič K., Trajanova M., Coric S., Rožič B. \& Šmuc A. 2018. Miocene paleogeography and biostratigraphy of the Slovenj Gradec Basin: a marine corridor between the Mediterranean and Central Paratethys. Geologica Carpathica 69: 528-544. https://doi.org/10.1515/geoca-2018-0031

Jasinska E., Knott B. \& McComb A.J. 1996. Root mats in ground water: a fauna-rich cave habitat. Journal of the North American Benthological Society 15: 508-519. https://doi.org/10.2307/1467802

Karátson D. 2014. Két vulkáni hegység között: a Dunakanyar kialakulása. In: Fésű J. \& Hála G. (eds) Börzsönyidék 5: A Börzsöny erdöi és vizei: 205-218. SzobEditors, A Börzsöny Múzeum Baráti Köre.

Katoh K., Rozewicki J. \& Yamada K.D. 2019. MAFFT online service: multiple sequence alignment, interactive sequence choice and visualization. Briefings in Bioinformatics 20: 1160-1166.

https://doi.org/10.1093/bib/bbx108

Kázmér M. 1990. Birth, life and death of the Pannonian Lake. Palaeogeography, Palaeoclimatology, Palaeoecology 79: 171-188. https://doi.org/10.1016/0031-0182(90)90111-J

Kerney M.P. \& Cameron R.A.D. 1979. Field Guide to the Land Snails of Britain and North-West Europe. Collins, London.

Krijgsman W., Hilgen F.J., Raffi I., Sierro F.J. \& Wilson D.S. 1999. Chronology, causes and progression of the Messinian salinity crisis. Nature 400: 652-655. https://doi.org/10.1038/23231

Kühn A.L. \& Haase M. 2020. QUIDDICH - QUick IDentification of DIagnostic CHaracters. Journal of Zoological Systematics and Evolutionary Research 58: 22-26. https://doi.org/10.1111/jzs.12347 
Kumar S., Stecher G., Li M., Knyaz C. \& Tamura K. 2018. MEGA X: Molecular Evolutionary Genetics Analysis across computing platforms. Molecular Biology and Evolution 35: 1547-1549.

https://doi.org/10.1093/molbev/msy096

Lanfear R., Calcott B., Ho S.Y.W. \& Guindon S. 2012. PartitionFinder: combined selection of partitioning schemes and substitution models for phylogenetic analysis. Molecular Biology and Evolution 29: 16591701. https://doi.org/10.1093/molbev/mss020

Leigh J.W. \& Bryant D. 2015. PopART: Full-feature software for haplotype network construction. Methods in Ecology and Evolution 6: 1110-1116. https://doi.org/10.1111/2041-210X.12410

Ložek V. \& Galvánek J. 1987. Geologická poloha a biostratigrafický rozbor chráneného prírodného výtvoru Mičinské travertíny. Ochrana prírody 8: 221-240.

Magyar I., Geary D. H. \& Müller P. 1999. Paleogeographic evolution of the Late Miocene Lake Pannon in Central Europe. Palaeogeography, Palaeoclimatology, Palaeoecology 147: 151-167.

https://doi.org/10.1016/S0031-0182(98)00155-2

Mezősi G. 2015. Magyarország Természetföldrajza. Akadémiai Kiadó, Budapest. https://doi.org/10.1556/9789630589765

Mike K. 1991. Magyarország ösvizrajza és felszíni vizeinek története. Aqua, Budapest.

Mitterová B. 1986. Čo ohrozuje Slovenský kras? Vesmír 65: 317-323.

Minh B.Q., Nguyen M.A. \& von Haeseler A. 2013. Ultrafast approximation for phylogenetic bootstrap. Molecular Biology and Evolution 30: 1188-1195. https://doi.org/10.1093/molbev/mst024

MolluscaBase. 2021. Hauffenia Pollonera, 1898. Available from https://molluscabase.org/aphia.php?p=taxdetails\&id=716229 [accessed 12 Jun. 2021].

Nation J.L. 1983. A new method using hexamethyldisilazane for preparation of soft insect tissues for scanning electron microscopy. Stain Technology 58: 347-351.

https://doi.org/10.3109/10520298309066811

Nekola J.C., Coles B. \& Horsák M. 2015. Species assignment in Pupilla (Gastropoda: Pulmonata: Pupillidae): integration of DNA-sequence data and conchology. Journal of Molluscan Studies 81: 196216. https://doi.org/10.1093/mollus/eyu083

Palumbi S.R., Martin A., Romano S., McMillan W.O., Stice L. \& Gabowski G. 1991. The Simple Fool's Guide to PCR. Department of Zoology and Kewalo Marine Laboratory, University of Hawaii, Honolulu.

Papp A. 1954. Die Molluskenfauna im Sarmat des Wiener Beckens. Mitteilungen der Geologischen Gesellschaft Wien 45: 1-112.

Ponder W.F., Wilke T., Zhang W.-H., Golding R.E., Fukuda H. \& Mason R.A.B. 2008. Edgbastonia alanwillsi n. gen. \& n. sp. (Tateinae: Hydrobiidae s.l.: Rissooidea: Caenogastropoda); a snail from an artesian spring group in western Queensland, Australia, convergent with some Asian Amnicolidae. Molluscan Research 28: 89-106.

Rambaut A., Drummond A.J., Xie D., Baele G. \& Suchard M.A. 2018. Posterior summarization in Bayesian phylogenetics using Tracer 1.7. Systematic Biology 67: 901-904.

https://doi.org/10.1093/sysbio/syy032

Reischütz A. 2000. Die Molluskenfauna der Sarmatschichten von Hautzendorf (Weinviertel, Niederösterreich). Nachrichtenblatt der Ersten Vorarlberger Malakologischen Gesellschaft 8: 21-27.

Reichütz A. \& Reischütz P. 2006. Beiträge zur Molluskenfauna Niederösterreichs XVII. Zwei interessante Hydrobiidae aus Niederösterreich. Heldia 6: 17-18. 
Ronquist F., Teslenko M., van der Mark P., Ayres D.L., Darling A., Höhna S., Larget B., Liu L., Suchard M.A. \& Huelsenbeck J.P. 2012. MrBayes 3.2: efficient Bayesian phylogenetic inference and model choice across a large model space. Systematic Biology 61: 539-542.

https://doi.org/10.1093/sysbio/sys029

Rundić L., Vasić N., Životić D., Bechtel A., Knežević S. \& Cvetkov V. 2016. The Pliocene Paludina Lake of Pannonian Basin: new evidence from northern Serbia. Annales Societatis Geologorum Poloniae 86: 185-209. https://doi.org/10.14241/asgp.2016.003

Rysiewska A., Prevorčnik S., Osikowski A., Hofman S., Beran L. \& Falniowski A. 2017. Phylogenetic relationships in Kerkia and introgression between Hauffenia and Kerkia (Caenogastropoda: Hydrobiidae). Journal of Zoological Systematics and Evolutionary Research 55: 106-117. https://doi.org/10.1111/jzs.12159

Schütt H. 1961. Weitere neue Süßwasser-Höhlenschnecken aus Dalmatien. Archiv für Molluskenkunde 90: $139-144$.

Somogyi S. 1961. Drainage pattern evolution of Hungary. Földrajzi Közlemények 9: 25-50.

Sümeghy J. 1955. A magyarországi pleisztocén összefoglaló ismertetése. Annual Report of the Geological Institute of Hungary 2: 395-403.

Simon, L. 2000. Volcanic structure of the youngest volcano in the Western Carpathians - the Putikov vršok volcano. Mineralia Slovaca 32: 241-242

Šteffek J. \& Grego J. 2002. True mollusc troglobite in Slovak Karst. Slovenský Kras 40: 175-176.

Šteffek J. \& Grego J. 2008. The current status of the genus cf. Hauffenia (Mollusca: Gastropoda: Hydrobiidae) distribution in Slovakian Karst. Slovenský Kras 46: 387-392.

Šteffek J., FalniowskiA., Szarowska M. \& Grego J. 2011. "Hauffenia” Pollonera, 1898 (Caenogastropoda: Hydrobiidae) in Slovakia: a preliminary report. Folia Malacologica 19: 1-7.

https://doi.org/10.2478/v10125-011-0006-7

Thompson J.D., Higgins D.G. \& Gibson T.J. 1994. CLUSTAL W: improving the sensitivity of progressive multiple sequence alignment through sequence weighting, position-specific gap penalties and weight matrix choice. Nucleic Acids Research 22: 4673-4680. https://doi.org/10.1093/nar/22.22.4673

Trifinopoulos J., Nguyen L.-T., von Haeseler A. \& Minh B.Q. 2016. W-IQ-TREE: a fast online phylogenetic tool for maximum likelihood analysis. Nucleic Acids Research 44: W232-W235.

https://doi.org/10.1093/nar/gkw256

Uhrin A. 2011. Vizszintváltozási ciklusok és kialakulásuk okai a késö-miocén Pannon-tó egyes részmedencéiben. PhD thesis, Földrajz-És Földtudományi Intézet Általános És Alkalmazott Földtani Tanszék, Budapest.

Verhaegen G., McElroy K.E., Bankers L., Neiman M. \& Haase M. 2018. Adaptive phenotypic plasticity in a clonal invader. Ecology and Evolution 8: 4465-4483. https://doi.org/10.1002/ece3.4009

Wade C.M. \& Mordan P.B. 2000. Evolution within the gastropod molluscs; using the ribosomal RNA gene-cluster as an indicator of phylogenetic relationships. Journal of Molluscan Studies 66: 565-570. https://doi.org/10.1093/mollus/66.4.565

Wilke T. 2003. Salenthydrobia gen. nov. (Rissooidea: Hydrobiidae): a potential relict of the Messinian salinity crisis. Zoological Journal of the Linnean Society 137: 319-336.

https://doi.org/10.1046/j.1096-3642.2003.00049.x 
Wilke T. \& Davis G.M. 2000. Infraspecific mitochondrial sequence diversity in Hydrobia ulvae and Hydrobia ventrosa (Hydrobiidae: Rissooidea: Gastropoda): do their different life histories affect biogeographic patterns and gene flow? Biological Journal of the Linnean Society 70: 89-105.

https://doi.org/10.1111/j.1095-8312.2000.tb00202.x

Wilke T., Davis G.M., Falniowski A., Giusti F., Bodon M. \& Szarowska M. 2000. Molecular systematics of Hydrobiidae (Mollusca: Gastropoda: Rissooidea): testing monophyly and phylogenetic relationships. Proceedings of the Academy of Natural Sciences of Philadelphia 151: 1-21. https://doi.org/10.1635/0097-3157(2001)151[0001:MSOHMG]2.0.CO;2

Xia X. 2018. DAMBE7: New and improved tools for data analysis in molecular biology and evolution. Molecular Biology and Evolution 35: 1550-1552. https://doi.org/10.1093/molbev/msy073

Xia X., Xie Z., Salemi M., Chen L. \& Wang Y. 2003. An index of substitution saturation and its application. Molecular Phylogenetics and Evolution 26: 1-7. https://doi.org/10.1016/S1055-7903(02)00326-3

Zielske S. \& Haase M. 2015. Molecular phylogeny and a modified approach of character-based barcoding refining the taxonomy of New Caledonian freshwater gastropods (Caenogastropoda, Truncatelloidea, Tateidae). Molecular Phylogenetics and Evolution 89: 171-181.

https://doi.org/10.1016/j.ympev.2015.04.020

Manuscript received: 28 June 2021

Manuscript accepted: 1 September 2021

Published on: 25 October 2021

Section editor: Rudy Jocqué

Section editor: Thierry Backeljau

Desk editor: Pepe Fernández

Printed versions of all papers are also deposited in the libraries of the institutes that are members of the EJT consortium: Muséum national d'histoire naturelle, Paris, France; Meise Botanic Garden, Belgium; Royal Museum for Central Africa, Tervuren, Belgium; Royal Belgian Institute of Natural Sciences, Brussels, Belgium; Natural History Museum of Denmark, Copenhagen, Denmark; Naturalis Biodiversity Center, Leiden, the Netherlands; Museo Nacional de Ciencias Naturales-CSIC, Madrid, Spain; Real Jardín Botánico de Madrid CSIC, Spain; Zoological Research Museum Alexander Koenig, Bonn, Germany; National Museum, Prague, Czech Republic.

\section{Supplementary files}

Supp. file 1. Phylogenetic trees. Outgroup taxa were pruned off. Specimens identified by two-digit locality code in bold, four digit individual DNA code, and orographic unit (see Table 1) or GenBank accession number; posterior probabilities or bootstrap support values at nodes; scale bars in substitutions per site; the sequence of $H$. tellinii (Pollonera, 1898) was generated by Ponder et al. (2008).

https://doi.org/10.5852/ejt.2021.775.1555.5329

Supp. file 2. Reference alignment of COI for identification of diagnostic molecular characters in FASTA format. Known species abbreviated by first three letters of epitheton followed by GenBank accession number. New sequences contain four digit individual code (see Table 1).

https://doi.org/10.5852/ejt.2021.775.1555.5331 
Supp. file 3. Uncorrected genetic distances (p-distances) between species of Hauffenia Pollonera, 1898 based on COI. Known species abbreviated by first three letters of epitheton followed by GenBank accession number. New sequences contain four digit individual code (see Table 1).

https://doi.org/10.5852/ejt.2021.775.1555.5333 